\title{
Article \\ Effect of an Aluminosilicate Disperse Additive on Behaviors of Autoclave Silicate Materials
}

\author{
Viktoriya Nelubova $^{1}$, Valeria Strokova ${ }^{1}\left(\mathbb{D}\right.$, Roman Fediuk $^{2, *}$, Mugahed Amran ${ }^{3,4}$ (D), Nikolai Vatin ${ }^{5}$ \\ and Yuriy Vasilev 6
}

1 Belgorod State Technological University Named after V.G. Shukhov, 308012 Belgorod, Russia; nelubova@list.ru (V.N.); vvstrokova@gmail.com (V.S.)

2 Polytechnic Institute, Far Eastern Federal University, 690922 Vladivostok, Russia

3 Department of Civil Engineering, College of Engineering, Prince Sattam Bin Abdulaziz University, Alkharj 11942, Saudi Arabia; m.amran@psau.edu.sa

4 Department of Civil Engineering, Faculty of Engineering and IT, Amran University, Amran 9677, Yemen

5 Peter the Great St. Petersburg Polytechnic University, 195251 St. Petersburg, Russia; vatin@mail.ru

6 Moscow Automobile and Road Construction University, 125319 Moscow, Russia; yu.vasilev@madi.ru

* Correspondence: fedyuk.rs@dvfu.ru; Tel.: +7-950-281-79-45

check for updates

Citation: Nelubova, V.; Strokova, V.; Fediuk, R.; Amran, M.; Vatin, N.; Vasilev, Y. Effect of an Aluminosilicate Disperse Additive on Behaviors of Autoclave Silicate Materials. Buildings 2021, 11, 239. https://doi.org/ 10.3390/buildings11060239

Academic Editor: João Castro-Gomes

Received: 3 May 2021

Accepted: 2 June 2021

Published: 3 June 2021

Publisher's Note: MDPI stays neutral with regard to jurisdictional claims in published maps and institutional affiliations.

Copyright: (c) 2021 by the authors. Licensee MDPI, Basel, Switzerland. This article is an open access article distributed under the terms and conditions of the Creative Commons Attribution (CC BY) license (https:// creativecommons.org/licenses/by/ $4.0 /)$.

\begin{abstract}
In this research, a phase formation in $\mathrm{CaO}-\mathrm{SiO}_{2}-\mathrm{Al}_{2} \mathrm{O}_{3}-\mathrm{H}_{2} \mathrm{O}$ binding system under hydrothermal conditions was studied. The novelty of this article lies in the quantitative full-profile X-ray diffraction (XRD) analysis used to determine kinetics of mineral formation in the binder system "lime-granite mineral modifier (GMM)". The formation of a polymineral system is described in detail, as well as quantitative relationships between mineral composition of newly formed phases and the binding mixture ratios were determined. Phenomenological model of mineral formation in a "lime-GMM" system under hydrothermal conditions was proposed. The results obtained allow the demonstration of this binding system as a binder that is characterized by superposition of hydration and geopolymerization. The properties (strength, density, water absorption, porosity) of compressed autoclave-hardened materials with the addition of a granite modifier introduced instead of part of the sand as an aggregate have been studied. The maximum increase in strength (more than 50\%) is observed at a modifier content of $15 \%$. This is due to the formation of a rational composition of neoplasms, the compaction of the structure of the pressed products and the optimization of their pore space, which is confirmed by the data of X-ray diffraction analysis, scanning electron microscopy and the method of gas adsorption.
\end{abstract}

Keywords: aluminosilicate; phase formation; mineral modifier; lime-sand brick; autoclave

\section{Introduction}

Autoclave materials are considered effective construction materials due to the combination of satisfactory strength and high frost resistance while maintaining a given degree of thermal insulation [1]. The classical technology for the production of autoclave-hardened products provides for the use of lime and silica-containing raw materials as the main components, as a result of the interaction during which the formation of calcium hydrosilicates of various basicity [2] occurs in hydrothermal conditions at elevated pressure. However, the depletion of "pure" quartz raw materials (sands) [3,4], as well as the formation of significant volumes of technogenic waste [5,6], including waste from crushing rocks of various compositions, sets the task of expanding the spectrum of raw materials used [7]. At the same time, due to the significant activation of raw materials under hydrothermal conditions, autoclave technology allows the use of raw materials even with a low quartz content $[8,9]$. Thus, granite dust formed during crushing of rocks was used as a replacement for traditional aggregates not only in the production of cement concrete [10,11], but also in the preparation of cellular autoclaved concretes [12,13]. 
Hydrothermal inorganic $\mathrm{CaO}-\mathrm{SiO}_{2}-\mathrm{Al}_{2} \mathrm{O}_{3}-\mathrm{H}_{2} \mathrm{O}$ binding systems, modified by reactive micro- and nano-scale components (nature and technogenic), are the basis for the development of a wide range of prospective construction materials with improved properties of thermal resistance $[14,15]$, corrosive stability $[16,17]$, biocompatibility $[18,19]$ and other performance characteristics compared to traditional analogues [20,21]. The final characteristics of the modified materials directly depend on the composition and properties of newly formed mineral phases during synthesis [22,23].

In this context, the study of hardening and mineral formation processes in hydrothermal systems is necessary for the production of high-quality, free-of-cement binder for use in the production of construction materials for different applications.

Problems of technological mineral- and petrogenesis during hydrothermal synthesis of phases of the $\mathrm{CaO}-\mathrm{SiO}_{2}-\mathrm{H}_{2} \mathrm{O}$ system attract practical interest during the production of lime-silica-based construction materials $[24,25]$. The typical silica-bearing component in $\mathrm{CaO}-\mathrm{SiO}_{2}$-binders is quartz [26,27]. However, its reserves peter out and hence initiate needs to find alternative raw materials such as quartz-feldspar mixtures and screenings of persilicic quartz-bearing extrusive rocks (e.g., granite) [28,29].

Arivumangai [30] revealed the high strength and durable properties of granite powder concrete. Gupta [31] established the effect on the mechanical properties of a cement-sand mortar containing granite powder waste. Sadek and El-Attar [32] reused marble and granite powders in self-compacting concrete. Scientists [33,34] have quite effectively used granite powder in cement materials as a fine aggregate. Researchers $[35,36]$ have proven the effectiveness of such a substitution in autoclaved aerated concrete. The addition of fiber to such composite cementitious materials can improve the mechanical properties $[37,38]$. The use of ashes of various genesis in autoclaved aerated concrete allows improved performances [39,40]. Nakhaev et al. [41] investigated regularities of the processes of formation of the structure and strength of a clinker-free binder with alkaline activation.

Thus, extending the $\mathrm{CaO}-\mathrm{SiO}_{2}-\mathrm{H}_{2} \mathrm{O}$ binding system to $\mathrm{CaO}-\mathrm{SiO}_{2}-\mathrm{Al}_{2} \mathrm{O}_{3}-\mathrm{H}_{2} \mathrm{O}$ is currently under consideration.

Classifications of newly formed phases (calcium-silicate hydrates) in the $\mathrm{CaO}-\mathrm{SiO}_{2}-$ $\mathrm{H}_{2} \mathrm{O}$ system under hydrothermal conditions is reported extensively by Garbev [42] and Richardson [43]. For the first time, various compositions for the $\mathrm{CaO}-\mathrm{SiO}_{2}-\mathrm{H}_{2} \mathrm{O}$ system were described, e.g., by Taylor [44], and a phase diagram for this system was proposed by Meller et al. [45].

Meller et al. [45] reported some data on paragenesis formation in a $\mathrm{CaO}-\mathrm{SiO}_{2}-\mathrm{Al}_{2} \mathrm{O}_{3}-$ $\mathrm{H}_{2} \mathrm{O}$ binding system in thermal range of $200-350{ }^{\circ} \mathrm{C}$ under hydrothermal conditions. The authors used quartz (content of $\mathrm{SiO}_{2}$ is $98 \%$; average particle size is $53 \mu \mathrm{m}$ ) and corundum (average particle size is 50-150 $\mu \mathrm{m}$ ). According to [45], the presence of $\mathrm{Al}_{2} \mathrm{O}_{3}$ in a CaO$\mathrm{SiO}_{2}-\mathrm{H}_{2} \mathrm{O}$ system leads to the formation of calcium-silicate hydrates as well as newlyformed phases such as katoite (hydrogarnet group) and bicchulite $\mathrm{Ca}_{2} \mathrm{Al}_{2} \mathrm{SiO}_{6} \cdot(\mathrm{OH})_{2}$ (zeolite group).

$\mathrm{Al}_{2} \mathrm{O}_{3}$ introduction increases the potential of $11 \AA$-tobermorite structures to transform into an anomalous form, i.e., a form that does not shrink during dehydration at elevated temperatures (above $300{ }^{\circ} \mathrm{C}$ of Mitsuda and Taylor [46]; also see Biagioni et al. [47]). This means that, based on the studied binding systems, it is possible to obtain non-shrinkable materials, which is an important factor in obtaining high-quality products with high physicomechanical performance.

One of the goals of this research was to study phase and structure formation in a $\mathrm{CaO}-\mathrm{SiO}_{2}-\mathrm{Al}_{2} \mathrm{O}_{3}-\mathrm{H}_{2} \mathrm{O}$ reference binding system, containing crystal aluminosilicates (feldspars as the main mineral component of granite)-based modifiers, in hydrothermal conditions (elevated temperature and pressure, saturated water vapor). This study has practical importance for the application of natural raw materials as a component of high efficiency building composites that vary in composition due to different origins of their natural resources. 
To increase reactivity of raw components during hydrothermal treatment, transformation of major mineral-forming components- $\mathrm{SiO}_{2}$ and $\mathrm{Al}_{2} \mathrm{O}_{3}$-from crystal form to gel (colloid solution) is desirable. In this research, the mineral modifier produced by long grinding of granite in water medium was used as a reactive component. Mechanical activation results in the formation of a polydisperse sedimentary stable system containing an amorphous (colloid) phase that has a strong impact on the modifier reactivity. Mechanical activation has been described extensively in mineral processing literature, e.g., by Kühnel and Van der Gaast [48], He et al. [49], Tromans and Meech [50] and Chaikina and Kryukova [51], and is considered a very effective means to enhance (hydrous) dissolution and reactivity. In addition, the effectiveness of this approach in obtaining highly active dispersed additives has been substantiated earlier by the research of the group of authors [52-55].

Taking into account the composition of modifiers and the hydrothermal conditions (as the basis of technology for a wide range of building materials) a deeper understanding of phase relations in the system $\mathrm{CaO}-\mathrm{SiO}_{2}-\mathrm{Al}_{2} \mathrm{O}_{3}-\mathrm{H}_{2} \mathrm{O}$ will provide knowledge to optimize performance characteristics and structural properties of the final products. In this regard, the purpose of this work is to study the phase formation in the system "lime-highly dispersed aluminosilicate additive" and the development of the composition of silicate bricks using a granite modifier as a partial replacement for the traditional aggregate.

\section{Materials and Methods}

The work is divided into two sections. In the first, the features of phase formation in the model system of the composition "lime-mineral granite modifier" are investigated. In this case, the ratio of components in the range of $1 / 1-1 / 3$ are used.

The second part is devoted to the development of the composition of silicate pressed bricks of autoclave hardening, consisting of a lime-sand binder, sand as a filler and an addition of a mineral modifier. The modifier was introduced instead of a part of the aggregate in the range of $0-20 \%$.

To study phase formation in the $\mathrm{CaO}-\mathrm{SiO}_{2}-\mathrm{Al}_{2} \mathrm{O}_{3}-\mathrm{H}_{2} \mathrm{O}$ binder system under hydrothermal conditions, prepared mixes of unslaked quicklime with granite mineral modifier (GMM) and plain tap water were exposed to hydrothermal conditions in an autoclave.

To study the effect of adding a granite modifier to the properties of autoclave materials, samples of pressed bricks were obtained, the raw material for which was quicklime, quartz sand and GMM.

\subsection{Materials Preparation}

Table 1 presents the characteristics of unslaked lump lime.

Table 1. Characteristics of unslaked lump lime.

\begin{tabular}{cc}
\hline Parameter & Value \\
\hline Content of $\mathrm{CaO}_{\text {free, }}$, wt. $\%$ & 80 \\
Content of $\mathrm{MgO}_{\text {free, }}$ wt. $\%$ & $\leq 5$ \\
Slaking period, $\min$ & 8 \\
\hline
\end{tabular}

Raw material for GMM production was screened from granite rocks (Poltava Deposit, Poltava, Ukraine) (Table 2).

Table 2. Chemical composition of granite mineral modifier and sand (wt.\%).

\begin{tabular}{lcccccccccc}
\hline & $\mathrm{SiO}_{\mathbf{2}}$ & $\mathrm{Al}_{\mathbf{2}} \mathbf{O}_{\mathbf{3}}$ & $\mathrm{Fe}_{\mathbf{2}} \mathbf{O}_{\mathbf{3}}$ & $\mathbf{C a O}$ & $\mathbf{M g O}$ & $\mathbf{S O}_{\mathbf{3}}$ & $\mathbf{K}_{\mathbf{2}} \mathbf{O}$ & $\mathbf{N a}_{\mathbf{2}} \mathbf{O}$ & $\mathbf{L O}$ & $\sum$ \\
\hline $\mathrm{GMM}$ & 69.2 & 15.7 & 3.35 & 3.14 & 0.89 & 0.09 & 2.06 & 4.29 & 0.75 & 99.47 \\
Sand & 91.4 & 4.18 & 0.6 & 1.69 & 0.69 & 0.19 & - & - & 1.23 & 100 \\
\hline
\end{tabular}


Both types of raw materials are silica-containing components with a high proportion of $\mathrm{SiO}_{2}$. This means their potentially high activity in terms of participation in the formation of hydrated compounds of various compositions under autoclave conditions. At the same time, granite was used as a raw material for obtaining an ultradispersed active additive. Sand was used as an aggregate in the production of pressed silicate bricks.

GMM was produced by grinding of screenings from granitic rock under water in a corundum-lined ball mill with $500 \mathrm{~L}$ capacity. Common steel equipment tends to contaminate the sample material with $\mathrm{Fe}$, which thus was avoided here [56,57]. About $0.20 \mathrm{wt} . \%$ of water glass (as a metasilicate) was added to keep $\mathrm{pH}$ within 8-9 during grinding. The added water glass also provides a critical concentration of solids together with critical dilution but does not affect the phase formation processes. This composition of the raw admixture provided required size distribution as well as reduced content of associated water. During the grinding process, sieving residues on a sieve with 63-mesh size were measured after each $2 \mathrm{~h}$ of grinding until the rest on a sieve retention was less than $1 \mathrm{wt} . \%$ (Table 3). Grinding for $12 \mathrm{~h}$ heated up the milling vessel containing the powdered product to $60-80^{\circ} \mathrm{C}$. As a result, a suspension with a polydisperse solid phase was obtained, which is associated with the grinding of rock-forming minerals of different hardness, with the formation of a colloidal phase with a particle size of less than $0.1 \mu \mathrm{m}$ at a concentration of $0.23 \%$ (Figure 1).

Table 3. Physical and mechanical characteristics of GMM.

\begin{tabular}{cc}
\hline Parameter & Value \\
\hline Humidity, $\%$ & 24 \\
Density, $\mathrm{kg} / \mathrm{m}^{3}$ & 2000 \\
Rest on a sieve (mesh size is $63 \mu \mathrm{m}), \%$ & $\leq 1$ \\
$\mathrm{pH}$ value of raw mixture suspension & 9 \\
\hline
\end{tabular}

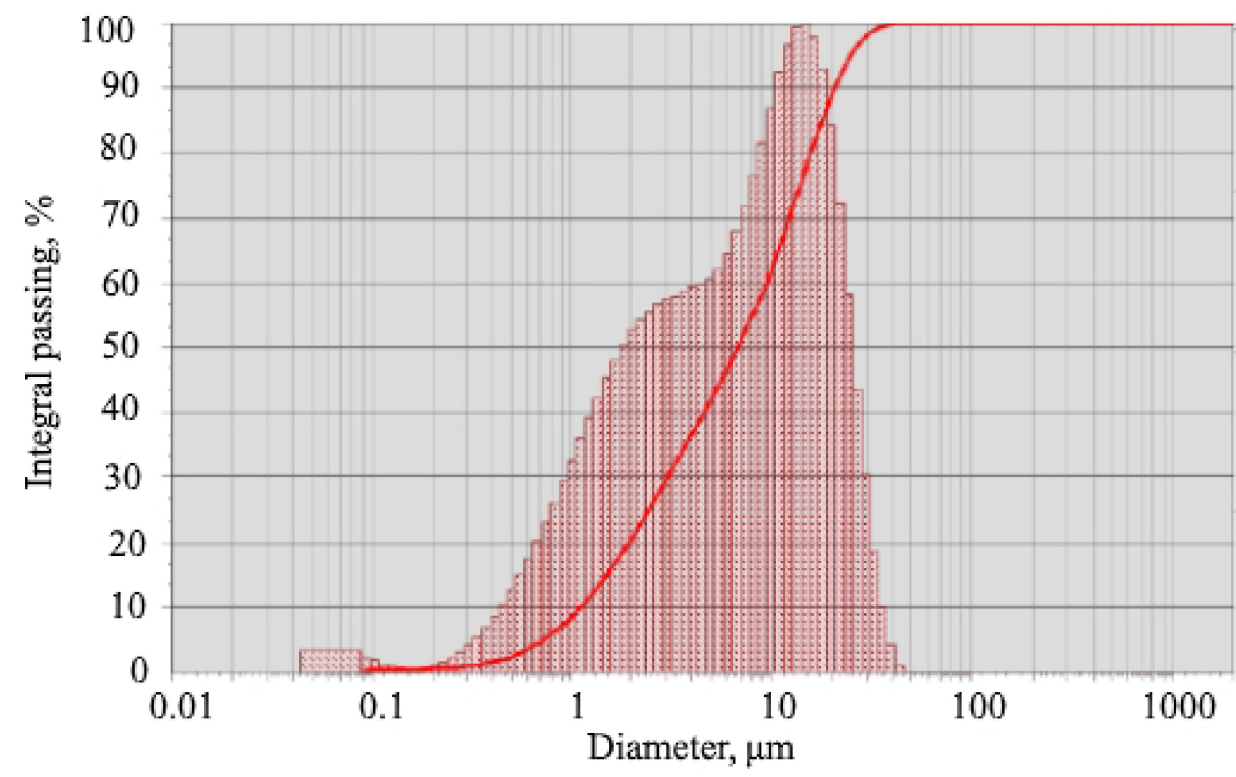

Figure 1. Particle size of the mineral modifier.

The sand of the Korochansk deposit (Korochansk, Russia) was used as an aggregate to obtain pressed materials (Table 2). The bulk density of sand is in the range of $1420-1440 \mathrm{~kg} / \mathrm{m}^{3}$. The size modulus is 0.98 .

Experimental (quicklime-aluminosilicate) binders were prepared by mixing lime and GMM in the weight ratios 1:1; 1:1.5; 1:2; 1:2.5 and 1:3. Mixes were put into a $500 \mathrm{~mL}$ steel autoclave (Kinematica, Geneva, Switzerland) lined with PTFE (magnetic mixer) and cured 
at $\mathrm{T}=190^{\circ} \mathrm{C}$ and $\mathrm{P}=1.2 \mathrm{MPa}$, according to the following regime: warm-up from ambient to nominal conditions $-2 \mathrm{~h}$; isothermal period at nominal conditions $-7 \mathrm{~h}$; cooling down to ambient conditions- $3 \mathrm{~h}$. After completed cool down, sample materials were recovered from the autoclave, gently ground in an agate mortar and pestle, dried in a covered glass petri dish at $50{ }^{\circ} \mathrm{C}$ overnight and then transferred to a glass vial for storage.

\subsection{Mix Design}

For the preparation of specimens of silicate bricks, a composite quicklime-silica binder was preliminarily obtained (Figure 2). For this, quicklime and quartz sand were ground in a ratio of $1 / 4$ in a ball mill with a uralite (non-metallic) lining until a specific surface area of $500 \mathrm{~m}^{2} / \mathrm{kg}$ was reached. The granite modifier was introduced as a replacement for a part of the quartz filler at a concentration of $0-20 \%$ with a step of $5 \%$ (Table 4 ).

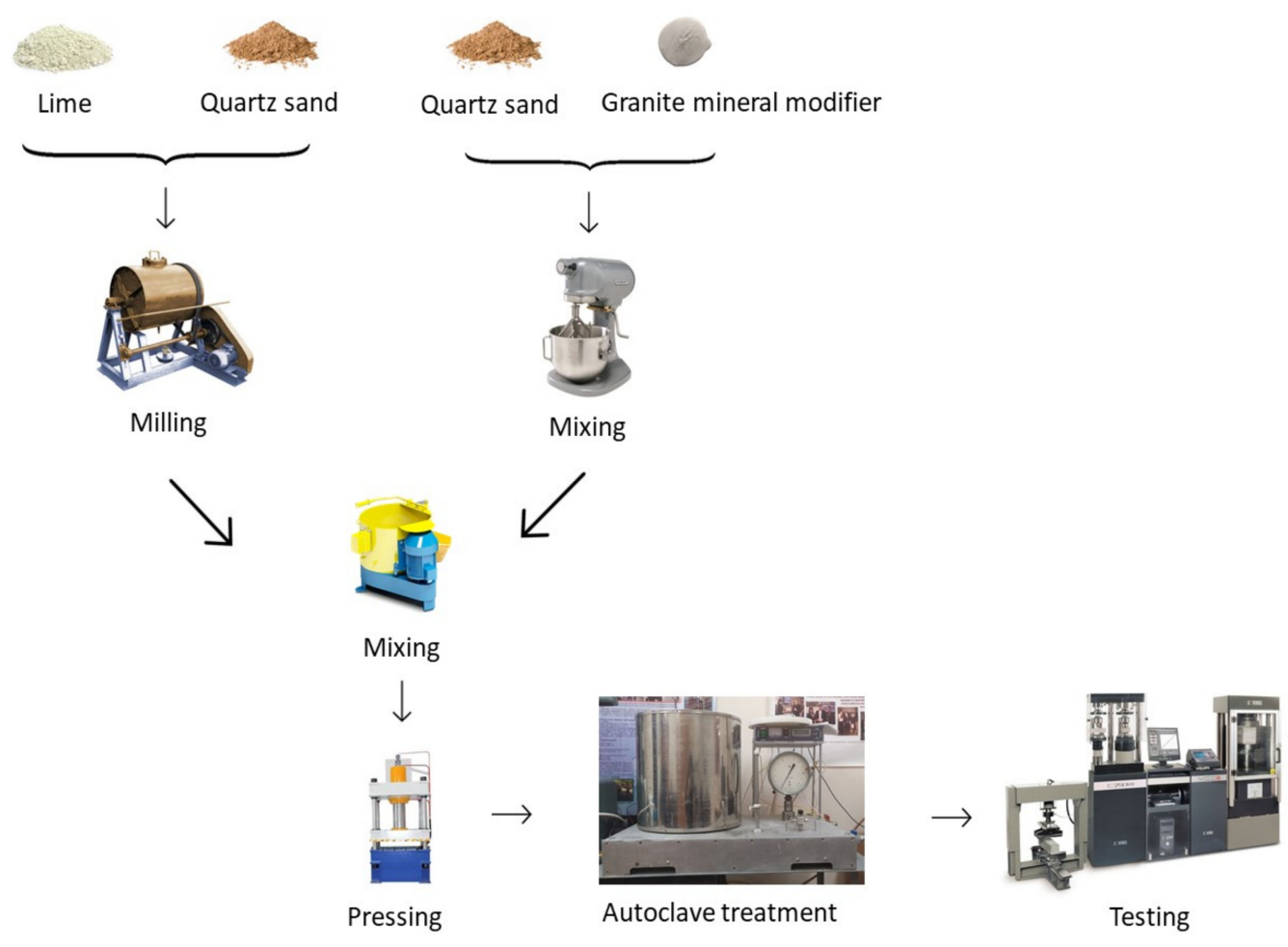

Figure 2. Flowchart for obtaining samples of silicate bricks.

Table 4. Compositions of pressed specimens.

\begin{tabular}{cccc}
\hline Mix ID & Sand & Quicklime & GMM \\
\hline 1 & 90 & 10 & 0 \\
2 & 85 & 10 & 5 \\
3 & 80 & 10 & 10 \\
4 & 75 & 10 & 15 \\
5 & 70 & 10 & 20 \\
\hline
\end{tabular}

Since the initial components have initially significantly different moisture content (aggregate-4\%, modifier-24\%), at the initial stage, sand as a filler and a mineral modifier are mixed by grinding until a homogeneous mass without lumps is achieved. Next, a lime-silica binder is introduced into the resulting mixture and everything is mixed together. The resulting mixture is moistened so that the final moisture content of the mixture is $6 \%$. Then, the mixture is kept in sealed vessels for $20 \mathrm{~min}$ to completely slake the lime. After that, specimen cylinders with a diameter and height of $5 \mathrm{~cm}$ are formed by the method of semi-dry pressing on a press at a specific pressure of $20 \mathrm{MPa}$. After that, the specimens are autoclaved according to the mode similar to the model specimens. 


\subsection{Materials Characterization}

Bulk chemical compositions of starting materials were determined spectrometrically by X-ray fluorescence (XRF). Powdered sample material was weighed to $0.6 \pm 0.0001 \mathrm{~g}$, mixed with $7 \times$ excess Li-tetraborate and fused at high temperature in a Pt-crucible to form a glass bead for analysis by the modified Claisse method. Glass beads were analyzed in an ARL 9900 X-ray Workstation (Thermo Fisher Scientific, Waltham, MA, USA) operated at $40 \mathrm{kV}$ and $40 \mathrm{~mA}$. Raw element data were ZAF-corrected (for atomic number, absorption and fluorescence) using proprietary software and recalculated to oxides assuming stoichiometry. Resulting net lower limits of detection (LLD) are approximately $0.10 \mathrm{wt} . \%$ (for $\mathrm{Na}$ ) or better. Loss of ignition (LOI) was determined gravimetrically in a separate procedure on a different aliquot.

Raw and autoclaved product materials were loaded in a dimpled aluminum sample holder and the surface was finished with a petrographic object carrier glass to ensure planarity. XRD patterns were collected in the same ARL 9900 X-ray WorkStation with CoK $\alpha$-radiation with $\lambda=1.790260 \AA$, over $2 \theta$ angular interval of $8-80^{\circ}$, with scan step size of $0.02^{\circ}$, counting time per step of $0.5 \mathrm{~s}$ and overall scan time of $1800 \mathrm{~s}$.

Crystalline phases were identified using the ICDD PDF-2 (Powder Diffraction File) database. Quantification of phases in binder systems is commonly done by Rietveld refinement, the effectiveness of which is substantiated by numerous authors [58-62]. However, here we applied the Derivative Difference Minimization (DDM) algorithm of Solovyov [63] as implemented in the DDM software version 1.95e (DDMNetworks Software) for fullprofile analysis, which has certain advantages for XRD patterns with complex backgrounds, using data from the Inorganic Crystal Structure Database (ICSD).

The microstructure of autoclaved products was studied using a high-resolution scanning electron microscope TESCAN MIRA 3 LMU (TESCAN, Brno, Czech Republic). The samples were taken under high vacuum conditions. Samples of the developed products were previously deposited with graphite materials.

For brick specimens after cooling, the average density, water absorption and ultimate strength in compression were determined. The average density is estimated by the ratio of the weight of the weighed specimens to their volume. To determine the water absorption, the specimens are placed in a vessel with a grid. The specimens are placed in one row in height with gaps between them of at least $2 \mathrm{~cm}$ on a lattice in a vessel with water at a temperature of $(20 \pm 5){ }^{\circ} \mathrm{C}$ so that the water level is $2-10 \mathrm{~cm}$ above the top of the specimens and kept for $48 \mathrm{~h}$. After the time has elapsed, the specimens are taken out, wiped and weighed, after which they are dried to a constant weight in an oven. Water absorption of specimens by weight $(W)$ in percent is calculated by the Equation (1):

$$
W=\frac{m_{1}-m}{m} \cdot 100
$$

where $m_{1}$ is the mass of the specimen saturated with water, g, and $m$ is the mass of the specimen dried to constant weight, $\mathrm{g}$.

The porosity of the pressed materials was determined by gas adsorption BET method using a Sorbi device (Porometer, Moscow, Russia).

\section{Results and Discussion}

\subsection{Phase Formation of the Model System "Quicklime-Dispersed GMM"}

Mineral composition of GMM in Table 5 demonstrates the presence of quartz, albite, biotite and hornblende as typical mineral phases as well as corundum as a result of grinding yield from corundum mill liner. Taking into account the addition of aluminum as corundum into GMM as well by using this grinding equipment, this phase was studied as one of the constituents of GMM in this research. 
Table 5. Mineral composition of GMM (wt.\%).

\begin{tabular}{cccccc}
\hline Quartz & Albite & Biotite & Hornblende & Corundum & $\sum$ \\
\hline 29.8 & 49.3 & 3.3 & 2.1 & 15.5 & 100.00 \\
\hline
\end{tabular}

XRD patterns of GMM demonstrates the variation in mineral composition of the binders with different "quicklime-GMM" ratio vs initial GMM (Figure 3). Newly formed minerals in the experimental samples can be divided into four groups:

(1) relics from original rockforming minerals (quartz, albite, biotite);

(2) contamination from grinding equipment (corundum);

(3) hydration and/or carbonation products of lime (portlandite, calcium carbonate);

(4) newly formed phases in the binding systems of $\mathrm{CaO}-\mathrm{SiO}_{2}-\mathrm{H}_{2} \mathrm{O}, \mathrm{CaO}-\mathrm{Al}_{2} \mathrm{O}_{3}-\mathrm{SiO}_{2}-$ $\mathrm{H}_{2} \mathrm{O}$ and $\mathrm{CaO}-\mathrm{Al}_{2} \mathrm{O}_{3}-\mathrm{H}_{2} \mathrm{O}$ (11 $\AA$-tobermorite, foshagite, wairakite, katoite).

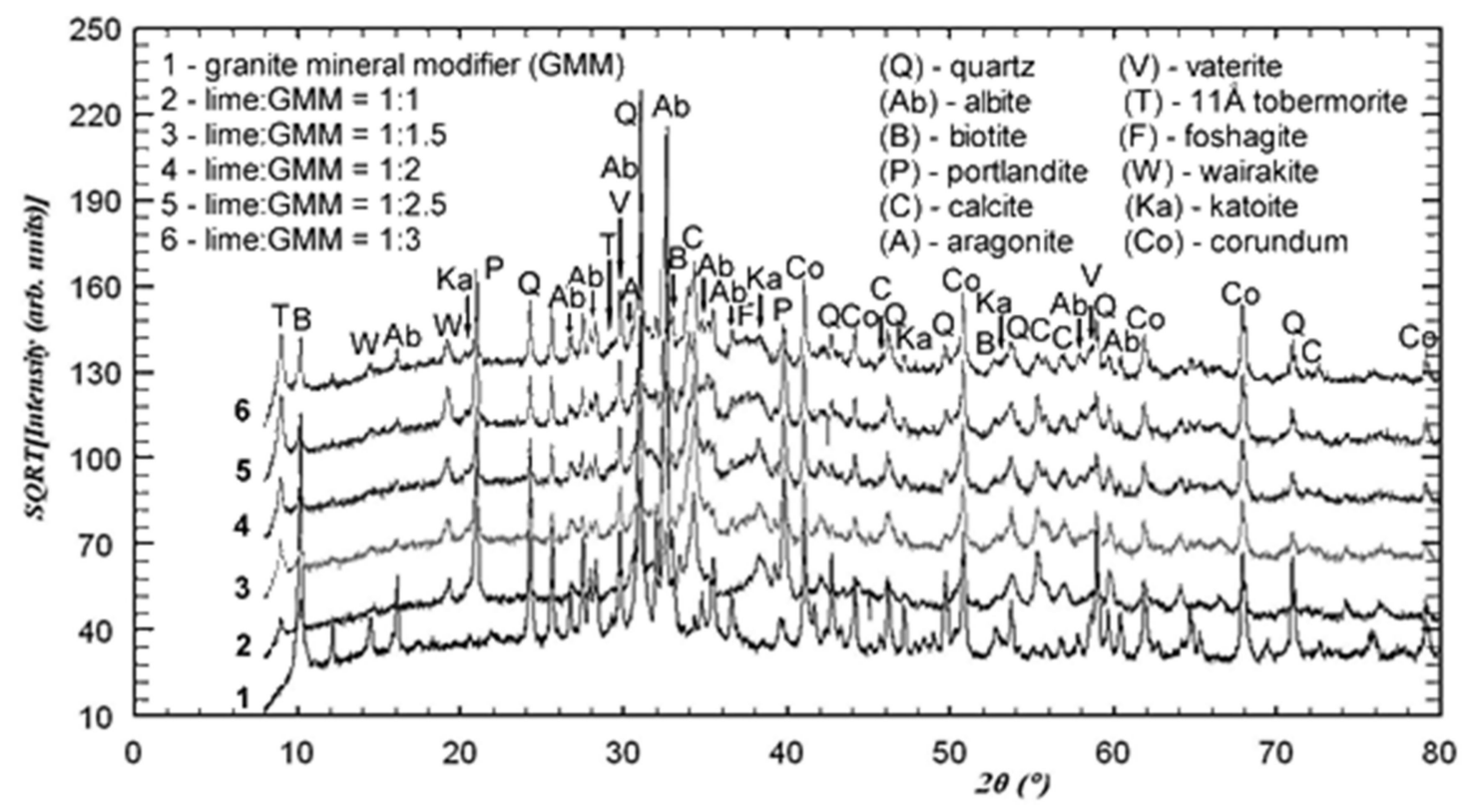

Figure 3. XRD patterns for GMM and autoclaved experimental samples. Visualization of weak reflections is realized by Y-axis scaling calibration in $\sqrt{ } \mathrm{I}$-values.

Full Profile XRD-analysis was realized with followings reference mineral structures: $\alpha$ quartz- $\mathrm{SiO}_{2}$ (74529-ICSD), albite- $\mathrm{Na}\left(\mathrm{AlSi}_{3} \mathrm{O}_{8}\right)(86319-\mathrm{ICSD})$, biotite- $\mathrm{K}\left(\mathrm{Fe}_{2} \cdot 554 \mathrm{Al}_{0.446}\right)$ $\left(\left(\mathrm{Al}_{1.55} \mathrm{Si}_{2.45}\right) \mathrm{O}_{10}\right)(\mathrm{OH})_{2}(95359-\mathrm{ICSD})$, portlandite- $\mathrm{Ca}(\mathrm{OH})_{2}(15471-\mathrm{ICSD})$, calcite- $\mathrm{CaCO}_{3}$ (80869-ICSD), aragonite- $\mathrm{CaCO}_{3}$ (32100-ICSD), vaterite- $\mathrm{CaCO}_{3}$ (27827-ICSD), $11 \AA$ tobermorite- $\mathrm{Ca}_{4}\left(\mathrm{Si}_{6} \mathrm{O}_{15}\right)(\mathrm{OH})_{2}\left(\mathrm{H}_{2} \mathrm{O}\right)_{5}(87690-\mathrm{ICSD})$, foshagite- $\mathrm{Ca}_{4}\left(\mathrm{Si}_{3} \mathrm{O}_{9}\right)(\mathrm{OH})_{2}(25818$ ICSD), wairakite (calcium analogue of analcime) $-\mathrm{Ca}_{0} \cdot{ }_{922} \mathrm{Na}_{0.08}\left(\mathrm{Al}_{2} \mathrm{Si}_{4} \mathrm{O}_{12}\right) \cdot 2 \mathrm{H}_{2} \mathrm{O}(98118$ ICSD), katoite- $\mathrm{Ca}_{3} \mathrm{Al}_{2}\left(\mathrm{O}_{4} \mathrm{H}_{4}\right)_{3}$ (94633-ICSD) and corundum- $\mathrm{Al}_{2} \mathrm{O}_{3}$ (9770-ICSD).

Due to the substantial complexity of the investigated system for the quantitative full-profile XRD, X-ray studies were performed without determining the concentration of the amorphous phase, which is not entirely correct when studying phase formation in such binding systems.

Nevertheless, the data in Table 6 demonstrate the interaction between silicates and aluminosilicates. Components in GMM and quicklime leads to the formation of different phases in the followings systems:

- $\mathrm{CaO}-\mathrm{SiO}_{2}-\mathrm{H}_{2} \mathrm{O}$ : calcium-silicate hydrates such as $11 \AA$ A-tobermorite and foshagite;

- $\mathrm{CaO}-\mathrm{Al}_{2} \mathrm{O}_{3}-\mathrm{SiO}_{2}-\mathrm{H}_{2} \mathrm{O}$ : zeolites such as wairakite;

- $\mathrm{CaO}-\mathrm{Al}_{2} \mathrm{O}_{3}-\mathrm{H}_{2} \mathrm{O}$ : hydrogarnets such as katoite. 
Table 6. Mineral composition of autoclaved "quicklime-GMM" binders (wt.\%).

\begin{tabular}{|c|c|c|c|c|c|c|}
\hline \multirow{2}{*}{\multicolumn{2}{|c|}{ Mineral }} & \multicolumn{5}{|c|}{ “Quicklime-GMM” Ratio (Content of GMM, wt.\%) } \\
\hline & & $1 / 1(50)$ & $1 / 1.5(60)$ & $1 / 2(67)$ & $1 / 2.5(71)$ & $1 / 3(75)$ \\
\hline \multirow{4}{*}{ GMM } & Quartz & $5.33 \pm 0.61$ & $6.26 \pm 0.42$ & $8.47 \pm 0.51$ & $8.26 \pm 0.59$ & $11.05 \pm 0.30$ \\
\hline & Albite & $9.43 \pm 0.51$ & $15.24 \pm 0.73$ & $18.92 \pm 0.72$ & $21.94 \pm 0.83$ & $28.71 \pm 1.13$ \\
\hline & Biotite & $2.32 \pm 0.21$ & $2.47 \pm 0.24$ & $2.23 \pm 0.25$ & $2.34 \pm 0.29$ & $2.27 \pm 0.18$ \\
\hline & Portlandite & $15.42 \pm 0.74$ & $9.43 \pm 0.84$ & $7.22 \pm 0.93$ & $10.70 \pm 0.82$ & $7.87 \pm 2.83$ \\
\hline \multirow{4}{*}{$\begin{array}{l}\text { Lime and products of } \\
\text { carbonization }\end{array}$} & Calcite & $13.31 \pm 1.08$ & $21.13 \pm 1.87$ & $15.01 \pm 2.03$ & $11.80 \pm 2.52$ & $11.33 \pm 1.91$ \\
\hline & Aragonite & $14.64 \pm 1.76$ & $6.90 \pm 1.42$ & $6.39 \pm 1.10$ & $4.05 \pm 0.92$ & $4.91 \pm 1.13$ \\
\hline & Vaterite & $16.04 \pm 2.11$ & $13.40 \pm 2.46$ & $15.11 \pm 2.00$ & $7.51 \pm 1.46$ & $6.26 \pm 1.21$ \\
\hline & $11 \AA$-tobermorite & $2.59 \pm 0.13$ & $3.88 \pm 0.23$ & $4.30 \pm 0.26$ & $7.38 \pm 0.46$ & $5.65 \pm 0.28$ \\
\hline \multirow{3}{*}{ Newly-formed phases } & Foshagite & $3.04 \pm 0.15$ & $2.36 \pm 0.12$ & $2.65 \pm 0.13$ & $4.77 \pm 0.23$ & $3.75 \pm 0.18$ \\
\hline & Wairakite & $2.17 \pm 0.13$ & $2.91 \pm 0.15$ & $2.85 \pm 0.14$ & $4.08 \pm 0.20$ & $2,31 \pm 0,10$ \\
\hline & Katoite & $9.59 \pm 0.57$ & $7.49 \pm 0.45$ & $7.31 \pm 0.36$ & $6.99 \pm 0.42$ & $5.01 \pm 0,10$ \\
\hline \multirow[t]{2}{*}{ Grinding yield } & Corundum & $6.14 \pm 0.28$ & $8.54 \pm 0.36$ & $9.54 \pm 0.29$ & $10.16 \pm 0.33$ & $10.88 \pm 0.32$ \\
\hline & & 100 & 99.99 & 100 & 100 & 99.99 \\
\hline
\end{tabular}

Mineral composition of the final binding system (in solid state) did not provide information about content variation of crystal phases as suppliers of major elements for formation of new phases that are responsible for mechanical strength characteristics of binding system. Initial concentrations of crystal components in GMM can be calculated with data from Table 5.

All synthesized systems are characterized by polyminerality and pronounced polystructurality, and, nevertheless, with a change in the amount of the modifier, differences in the morphostructure of the most coarse crystalline phases located in the pore space are observed. Thus, in samples with a ratio of $1 / 1$, the cleavage surface is represented by fairly uniform new growths of a predominantly columnar structure (Figure 4a,b), which are formed on a fine-structured globular mass no more than $1 \mu \mathrm{m}$ in size.

In the microstructure of samples with a component ratio of $1 / 1.5$, anisometric crystal formations in the form of petals predominate-flat elongated crystals (Figure 4c,d), related to low-basic calcium silicate hydrates, and lamellar crystals of portlandite and its carbonization products, which are a substrate for the growth of hydrosilicate and hydroaluminosilicate new growths of various compositions.

An increase in the proportion of the modifier in the samples leads to a decrease in the crystallized new growths (Figure 4e-j). However, it is known that the strength of autoclave materials is directly proportional to the concentration of the amorphous phase. Against the background of an ultradispersed globular mass, which cannot be identified either by structure or by XRD patterns, ultradispersed prismatic to pyramidal formations were noted (Figure 4h).

The data on the strength of model samples of binders correlate well with the phase composition and microstructural features of the synthesized stone (Figure 5). An increase in the content of hydrosilicate binder and zeolite in combination with an increase in the proportion of amorphous substance in the bulk of the stone leads to a smooth increase in the strength of the samples. 


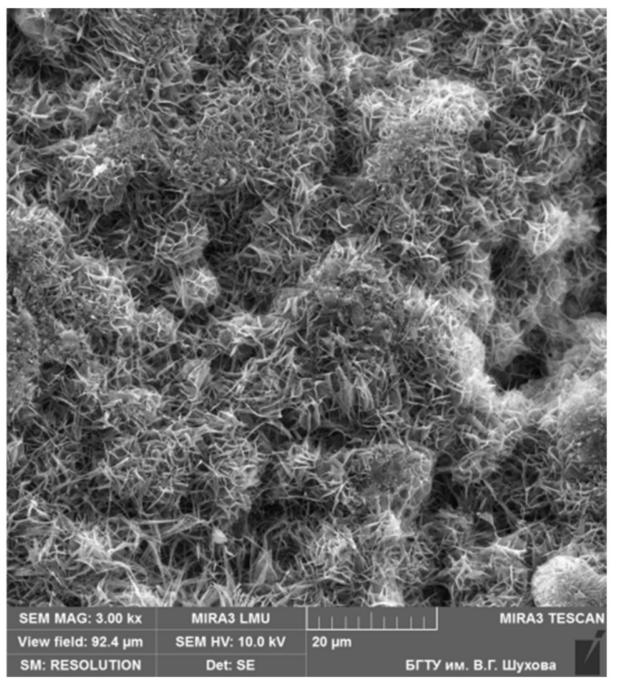

(a)

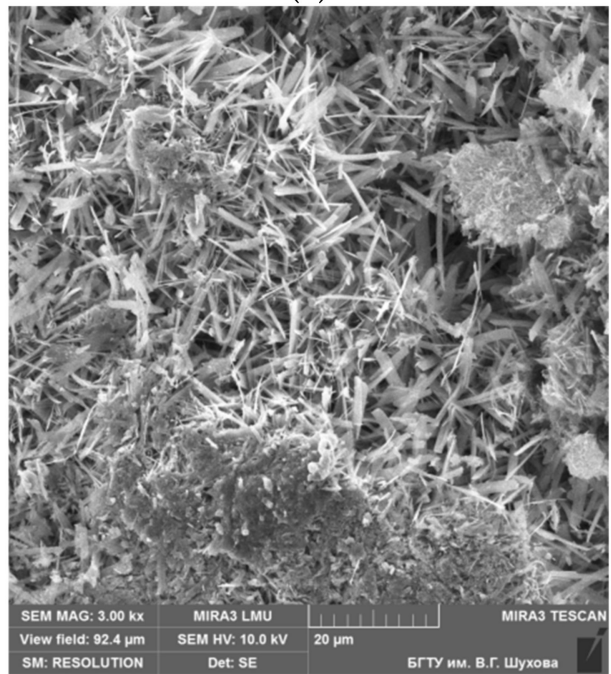

(c)

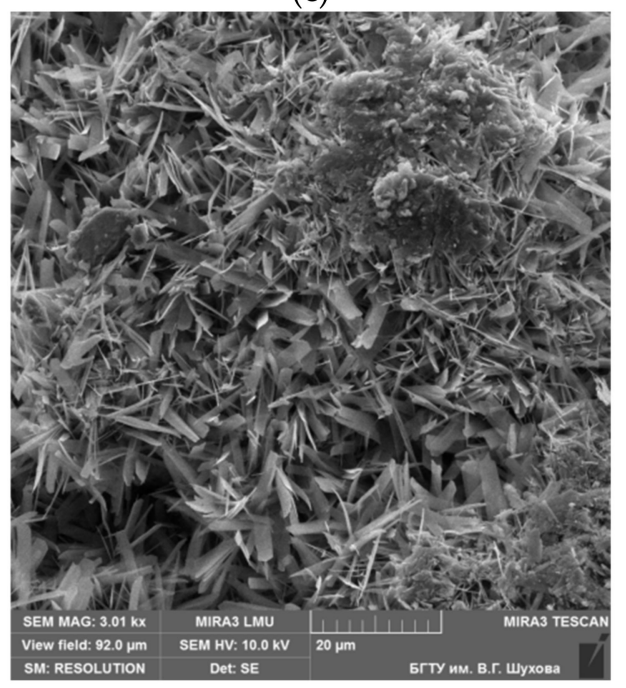

(e)

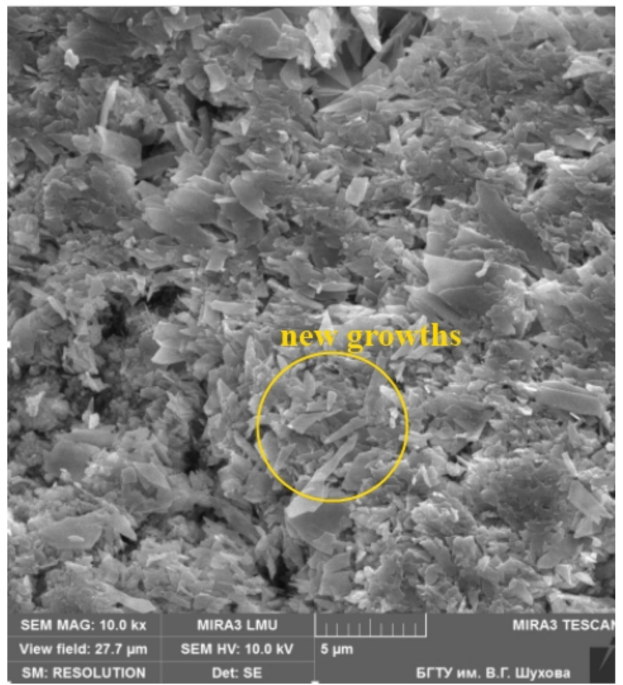

(b)

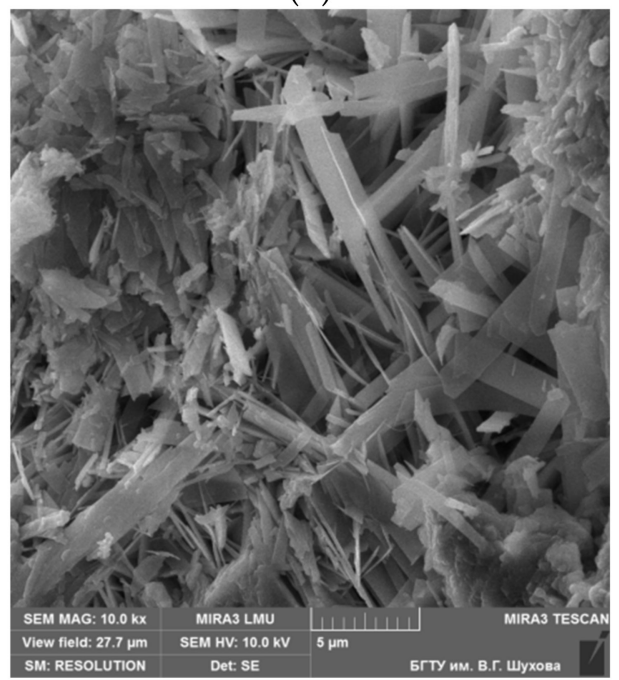

(d)

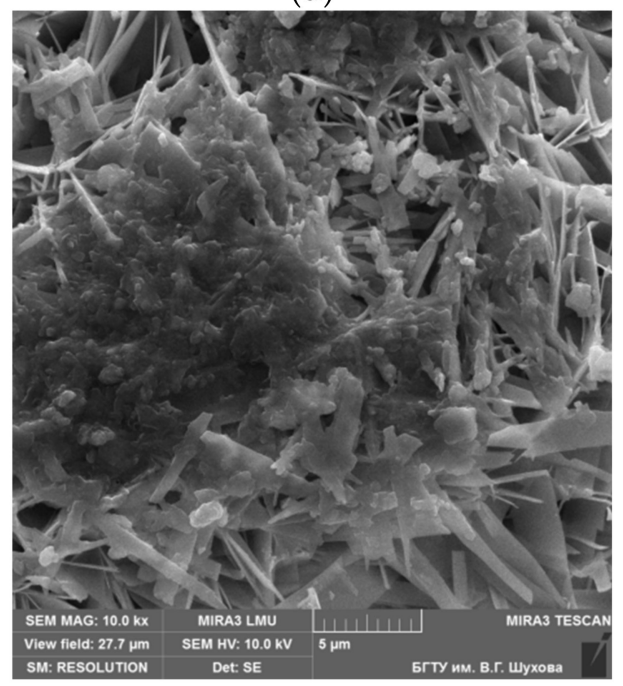

(f)

Figure 4. Cont. 


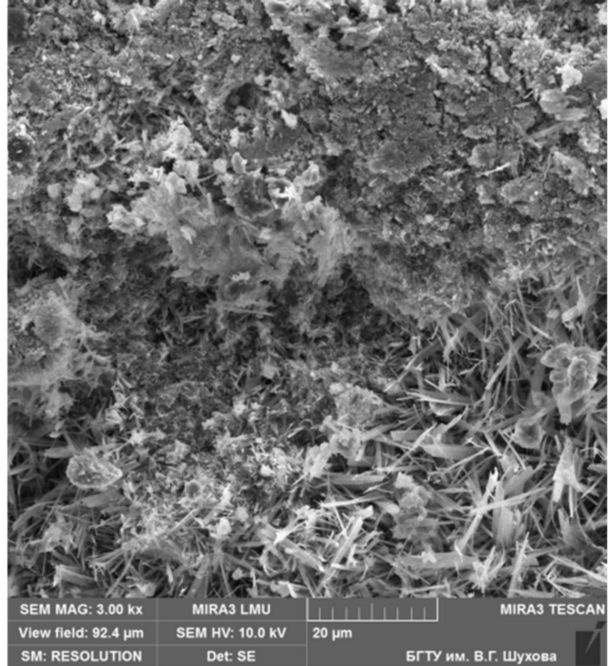

(g)

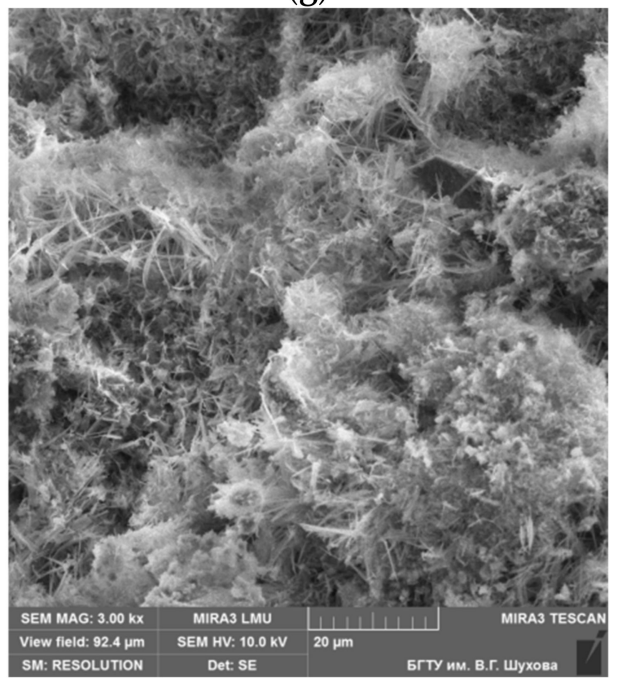

(i)

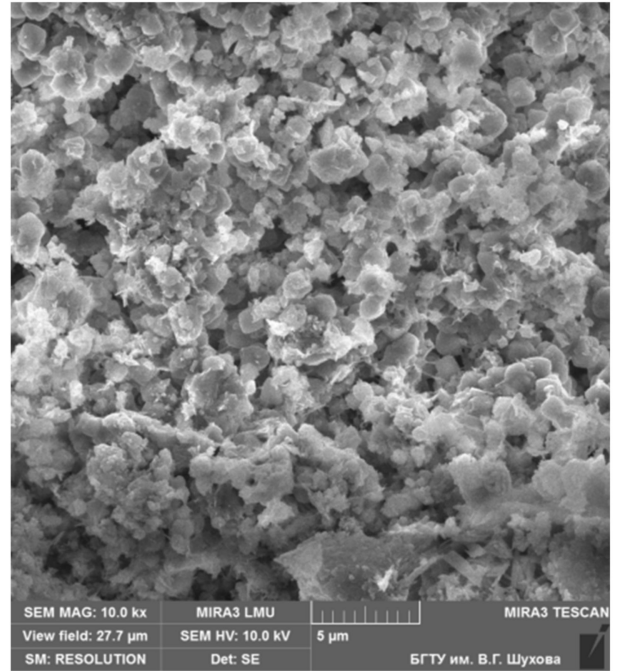

(h)

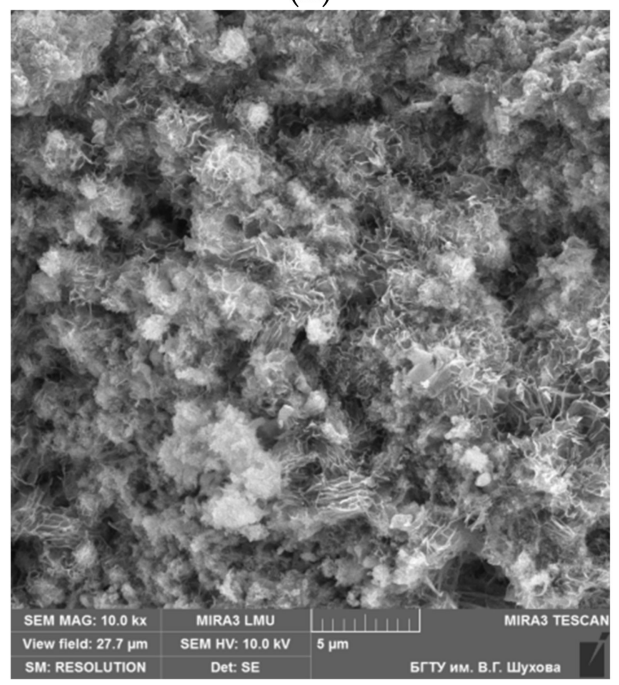

(j)

Figure 4. Microstructure of model samples with the ratio "quicklime/GMM": (a,b) 1/1; (c,d) 1/1.5; (e,f) 1/2; (g,h) 1/2.5; (i,j) $1 / 3$.

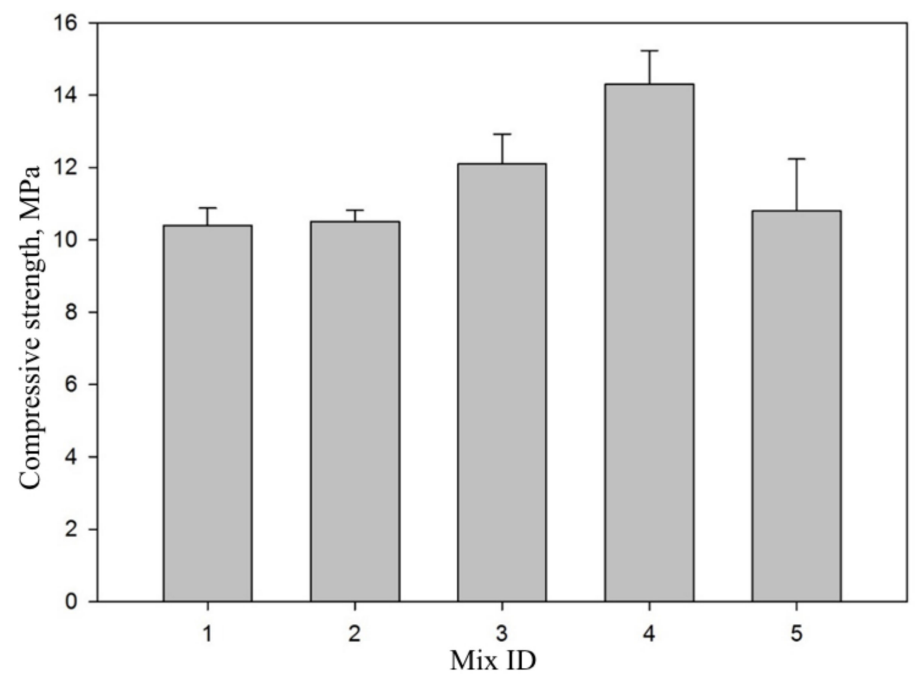

Figure 5. Compressive strength of model samples with the ratio "quicklime/GMM". 
According to the data obtained (Table 6), adding the modifier to lime and subsequent autoclaving (hydrothermal treatment) does not change the concentration of the main mineral phases of the system (quartz, lime feldspar and lime) due to the fact that they participate in the processes of hydrothermal mineral formation. As a result, their content in the final product after hydrothermal treatment will be less than in the initial state of the "lime-modifier mixture". Thus, quartz and lime feldspar, dissolving in the environment with a high $\mathrm{pH}$, initiate the formation of $\mathrm{CSH}$ and $\mathrm{CASH}$ gels, from which calcium-silicate hydrates crystallize.

Lime, which did not react to the formation of CSH and CASH gels, hydrates to portlandite, which reacts with $\mathrm{CO}_{2}$ to form calcium carbonates, i.e., calcite, aragonite and vaterite. The change in the sum of these minerals, depending on the degree of dilution of lime with the granite modifier, is characterized only by the influence of external (atmospheric) factors on the mineral formation and it does not have relevance for hydrothermal mineralization. Nevertheless, based on experimental data, it is possible to represent the dependence of the concentration of total calcium carbonates on the content of the modifier (Figure 6).

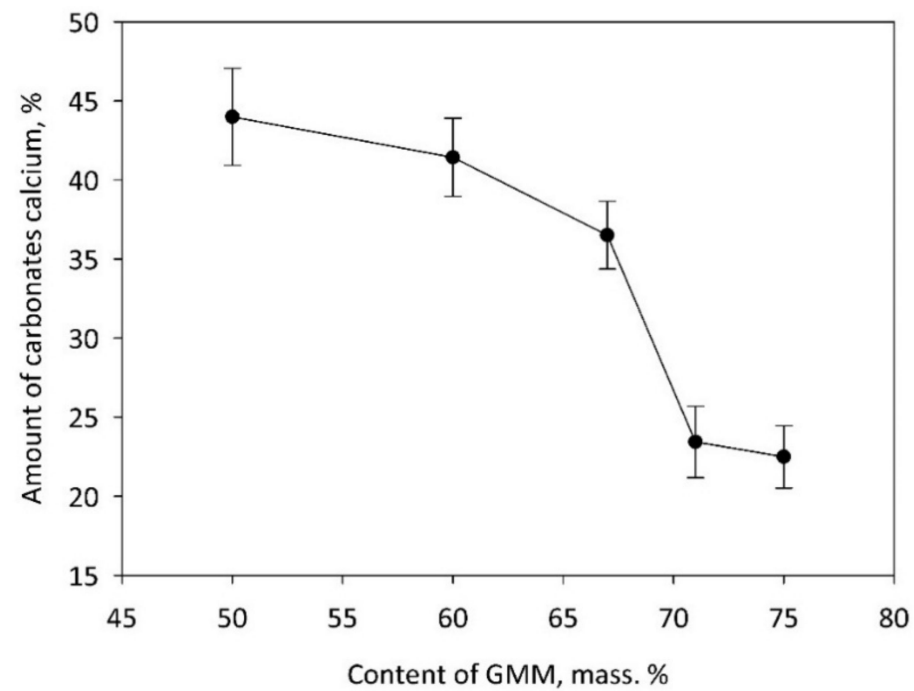

Figure 6. The changes in the concentration of carbonates calcium depending on the content of the modifier in the model system.

As follows from the relation mentioned above, the amount of calcium carbonate decreases with the increase in the amount of granite component.

Below, we consider in more detail the processes and features of the formation of hydrated phases. Figure 7 demonstrates variation in concentrations of quartz and albite, taking into account different concentrations of GMM in the binding system.

In comparison with the theoretical model system, the reduced amount of quartz and albite in the experiment could be explained with the dissolution of minerals of GMM in alkaline media due to lime dissociation during autoclave curing.

Determination of lime content in the system was difficult as lime-bearing components are not only $\mathrm{CaO}$. Portlandite and other polymorphous modifications of $\mathrm{CaCO}_{3}$-calcite, aragonite and vaterite had to be considered, as well.

Therefore, assuming the hypothesis that lime-bearing components in reference systems were represented by $100 \%$ content of $\mathrm{CaO}$ (which is unlikely), the calculation of the actual lime content was calculated with the following equations:

$$
\mathrm{C}_{\mathrm{CaO}}^{\mathrm{Ca}(\mathrm{OH})_{2}}=\frac{\mathrm{C}_{\mathrm{Ca}(\mathrm{OH})_{2}} \cdot\left(\mathrm{M}_{\mathrm{Ca}(\mathrm{OH})_{2}}-\mathrm{M}_{\mathrm{H}_{2} \mathrm{O}}\right)}{\mathrm{M}_{\mathrm{Ca}(\mathrm{OH})_{2}}}
$$


and

$$
\mathrm{C}_{\mathrm{CaO}}^{\mathrm{CaCO}}{ }_{3}=\frac{\mathrm{C}_{\mathrm{CaCO}_{3}} \cdot\left(\mathrm{M}_{\mathrm{CaCO}_{3}}-\mathrm{M}_{\mathrm{CO}_{2}}\right)}{\mathrm{M}_{\mathrm{CaCO}_{3}}},
$$

where $\mathrm{C}_{\mathrm{CaO}}^{\mathrm{Ca}(\mathrm{OH})_{2}}$ and $\mathrm{C}_{\mathrm{CaO}}^{\mathrm{CaCO}_{3}}$ are concentrations (wt.\%) of $\mathrm{CaO}$ in portlandite and calcium carbonate, and $\mathrm{M}_{\mathrm{CaCO}_{3}}, \mathrm{M}_{\mathrm{Ca}(\mathrm{OH})_{2}}$ and $\mathrm{M}_{\mathrm{CaCO}_{3}}$ are molecular weights for $\mathrm{CaCO}_{3}$, portlandite and calcium carbonate, respectively. The calculated data are presented in Table 7; the variation in $\mathrm{CaO}$ content is plotted in Figure 8.

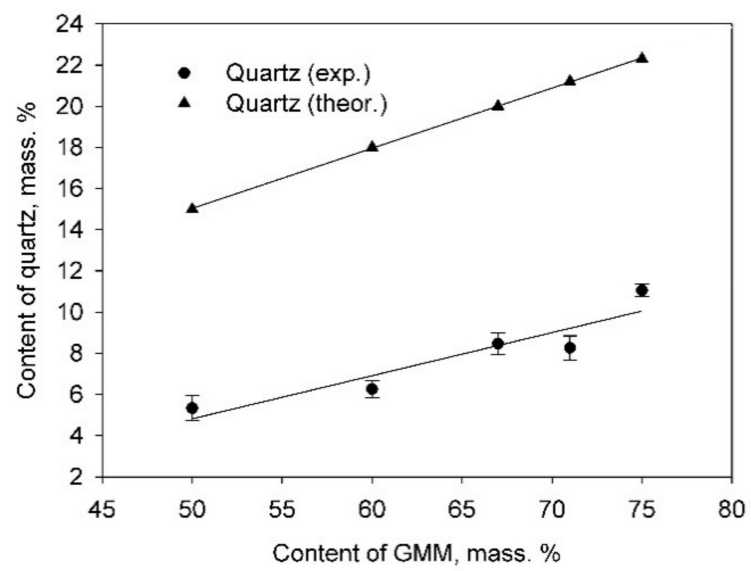

(a)

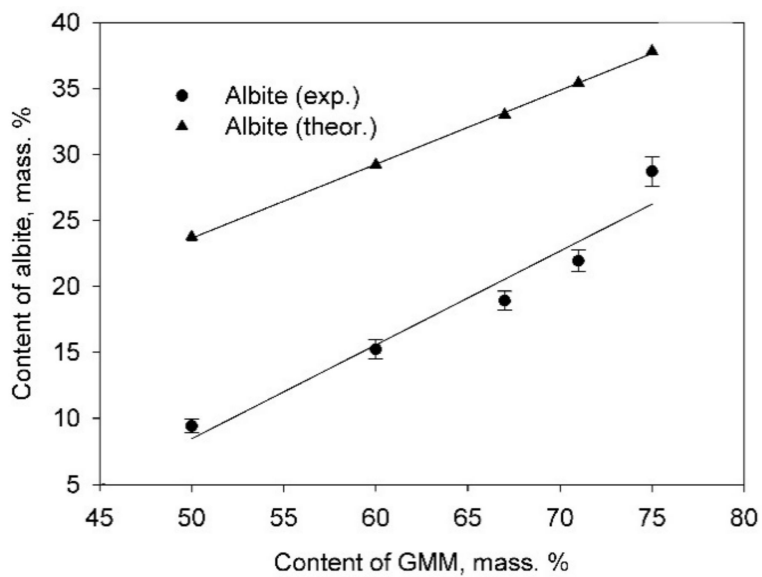

(b)

Figure 7. Theoretical and experimental data lines of content variations for quartz (a) and albite (b) in the binding system. Experimental data are approximated by linear function.

Table 7. Content of $\mathrm{CaO}$ in autoclave “quicklime-GMM" binding systems (\%wt.).

\begin{tabular}{ccccc}
\hline \multicolumn{5}{c}{ “Quicklime-GMM" Ratio (\%wt. of GMM) } \\
\hline $1 / 1(50)$ & $1 / 1.5(60)$ & $1 / 2(67)$ & $1 / 2.5(71)$ & $1 / 3(75)$ \\
\hline 36.32 & 30.35 & 25.92 & 21.19 & 18.57 \\
\hline
\end{tabular}

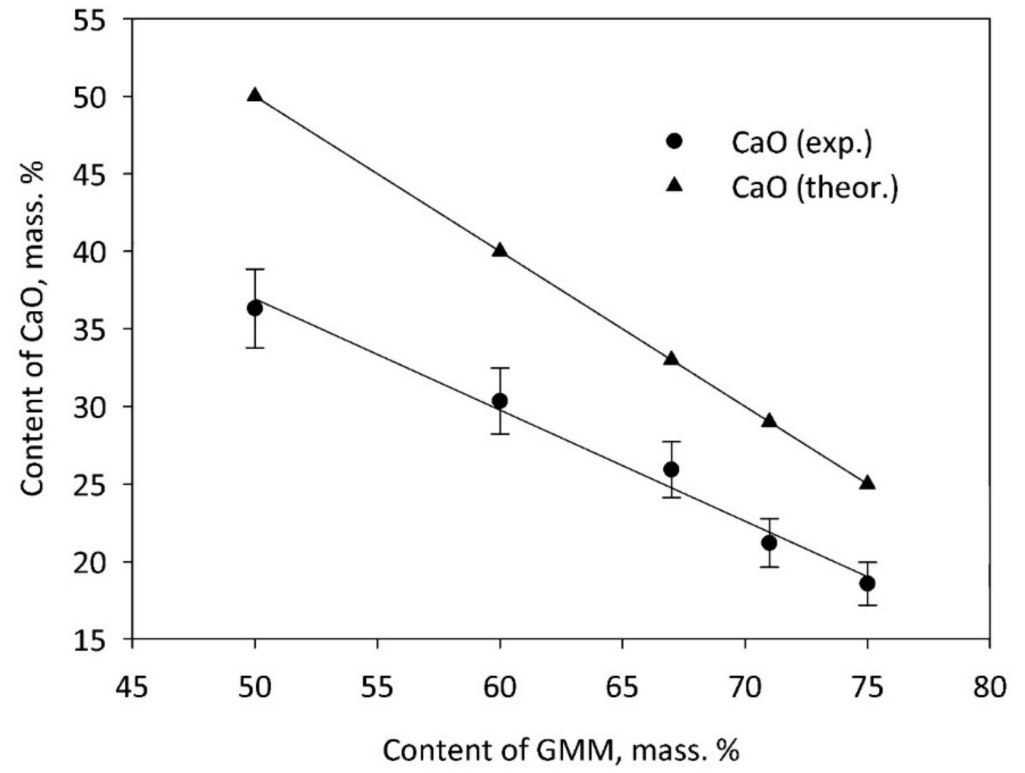

Figure 8. Theoretical and experimental lines of content variations for $\mathrm{CaO}$ in the binding system.

According to Figure 8, the hardening process in the reference binding systems "limeGMM" under autoclave curing is followed by intensive dissolution of rock-forming crystal 
components such as quartz, albite and lime to $\mathrm{CaO}-\mathrm{Al}_{2} \mathrm{O}_{3}-\mathrm{SiO}_{2}-\mathrm{H}_{2} \mathrm{O}$ gel formation. Some aluminosilicate gel (colloid solution) was formed during mechanoactivation, i.e., GMM production. Quantitative data of the GMM composition were not determined. Therefore, XRD data refer only to the autoclaved reference system of the CASH gel formed during the hardening process.

Reactivity of quartz and albite vs. lime in the reference systems is shown in Figure 9. The results obtained correspond to the expected solubility of silicates in an alkaline environment.

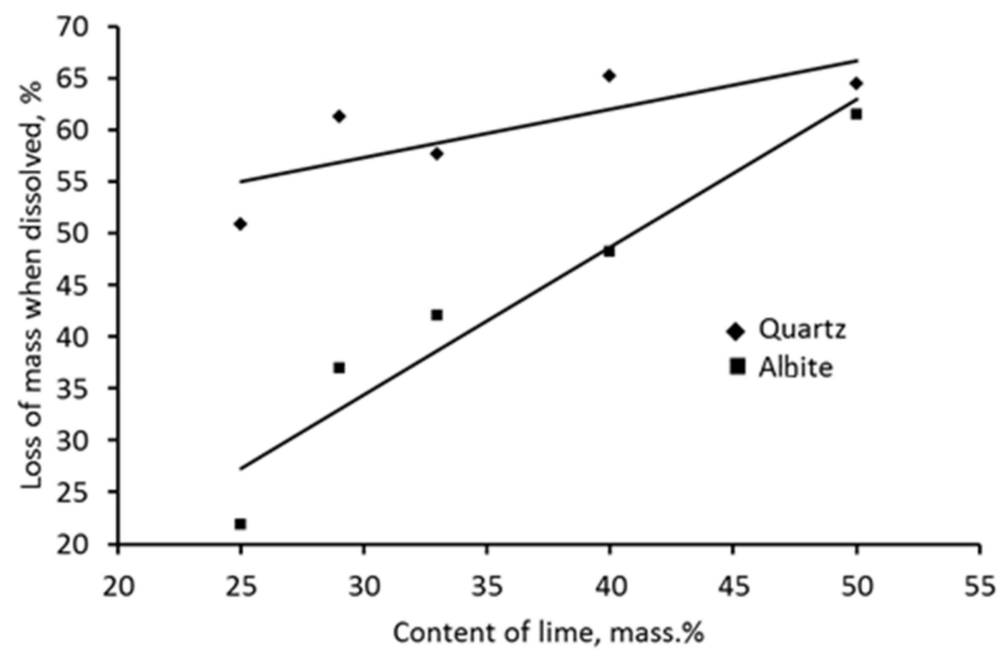

Figure 9. Reactivity of quartz and albite vs. lime in the reference systems.

The authors do not have experimental confirmation of presence of two types of gel, $\mathrm{CaO}-\mathrm{SiO}_{2}-\mathrm{H}_{2} \mathrm{O}(\mathrm{C}-\mathrm{S}-\mathrm{H})$ gel and $\mathrm{CaO}-\mathrm{Al}_{2} \mathrm{O}_{3}-\mathrm{SiO}_{2}-\mathrm{H}_{2} \mathrm{O}(\mathrm{C}-\mathrm{S}-\mathrm{A}-\mathrm{H})$ gel. Yet, the effect of the reference system composition by variation of the $\mathrm{CaO} / \mathrm{SiO}_{2}$ ratio (for $\mathrm{CaO}-\mathrm{SiO}_{2}-\mathrm{H}_{2} \mathrm{O}$ gel) and $\mathrm{CaO} /\left(\mathrm{Al}_{2} \mathrm{O}_{3}+\mathrm{SiO}_{2}\right)$ ratio (for $\mathrm{CaO}-\mathrm{Al}_{2} \mathrm{O}_{3}-\mathrm{SiO}_{2}-\mathrm{H}_{2} \mathrm{O}$ gel) can be demonstrated as shown in Figure 10a. These data were calculated from values content of quartz, albite and lime. They have correlation with the same data for $11 \AA$ A-tobermorite, foshagite and wairakite (Figure 10b).

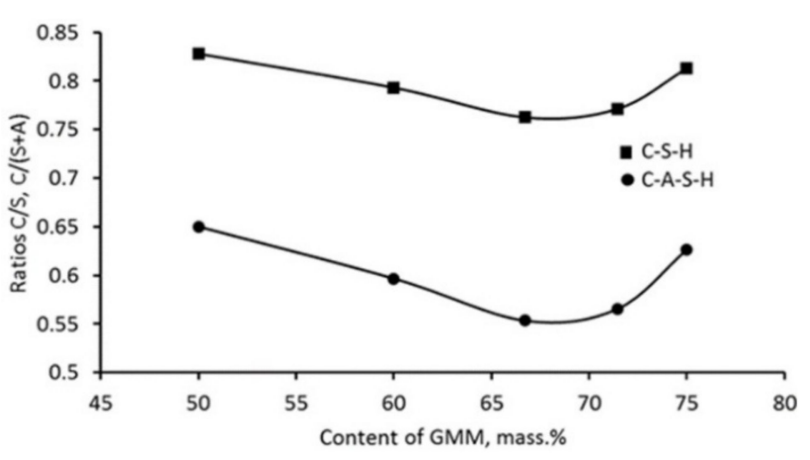

(a)

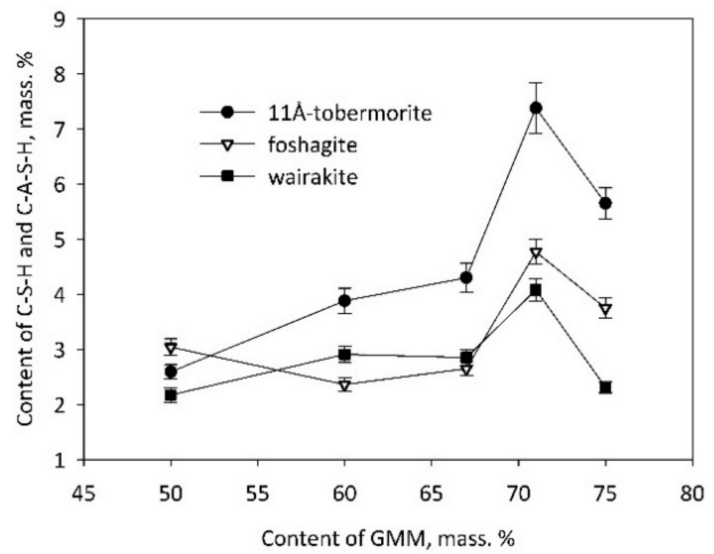

(b)

Figure 10. Effect of $\mathrm{CaO} / \mathrm{SiO}_{2}$ and $\mathrm{CaO} /\left(\mathrm{Al}_{2} \mathrm{O}_{3}+\mathrm{SiO}_{2}\right)$ ratios in $\mathrm{CaO}-\mathrm{SiO}_{2}-\mathrm{H}_{2} \mathrm{O}$ gel and $\mathrm{CaO}-\mathrm{Al}_{2} \mathrm{O}_{3}-\mathrm{SiO}_{2}-\mathrm{H}_{2} \mathrm{O}$ gel $(\mathbf{a})$ and content of newly-formed phases $(\mathbf{b})$ on the binding system composition.

The graphs in Figure 10a show the dependency of the basic $\mathrm{C} / \mathrm{S}=$ content $\mathrm{CaO} /$ content $\mathrm{SiO}_{2}$ for $\mathrm{CSH}$ gel and $\mathrm{C} /(\mathrm{S}+\mathrm{A})=$ content $\mathrm{CaO} /$ content $\left(\mathrm{SiO}_{2}+\mathrm{Al}_{2} \mathrm{O}_{3}\right)$ for $\mathrm{CASH}$ gel on the content in the binding system of granite component. These $\mathrm{X}$-ray amorphous formations were always present in autoclave curing binders. Estimated values of $C / S$ and $C /(S+A)$ 
show that in the described experiment, $\mathrm{CSH}$ and $\mathrm{CASH}$ gels of low alkalinity are formed: $\mathrm{C} / \mathrm{S}<1$ and $\mathrm{C} /(\mathrm{S}+\mathrm{A})<1$.

It is widely accepted that this has a positive effect on the mechanical strength properties of binders. These gels are the basis for the crystallization of calcium-silicate hydrates and hydroaluminosilicates from them. In this case, $11 \AA$ A-tobermorite, foshagite and wairakite were formed and confirmed by XRD patterns.

Figure $10 \mathrm{~b}$ shows the concentration dependences of the newly formed compounds (11 A-tobermorite, foshagite and wairakite) on the content of granite modifier in the binding system. It is characteristic that the concentration maxima of the crystallized calcium-silicate hydrates and hydroaluminosilicates coincide (according to the concentration of granite component) with the minimum values $\mathrm{C} / \mathrm{S}$ and $\mathrm{C} /(\mathrm{S}+\mathrm{A})$ relations for $\mathrm{CSH}$ and for $\mathrm{CASH}$ gel. It confirmed that the gels are the basis for the crystallization of $11 \AA$-tobermorite, foshagite and wairakite.

Among of newly formed phases, a katoite (hydrogarnet group) takes place. The authors suppose that this mineral was formed not from $\mathrm{CaO}-\mathrm{Al}_{2} \mathrm{O}_{3}-\mathrm{SiO}_{2}-\mathrm{H}_{2} \mathrm{O}$ gel but due to the dissolution of corundum (a product of grinding yield) in alkaline media.

It is necessary to note that the dynamics of development of the amount of katoite were inversely proportional to corundum: with an increase in the dosage of GMM and, accordingly, an increase in the amount of corundum, a decrease in the number of katoite in the system was observed (Figure 11). At the same time, the directivity of the dependence of katoite on the content in the granitic system coincides with the trend of the $\mathrm{CaO}$ dependence. This observation could be explained by a stronger influence of lime concentration in the binder than alumina, which was consistent with the highly basic nature of katoite $\left(\mathrm{Ca}_{3} \mathrm{Al}_{2}\right.$ $\left.\left((\mathrm{OH})_{4}\right)_{3}\right)$, in which the ratio is $\mathrm{CaO} / \mathrm{Al}_{2} \mathrm{O}_{3}=3$. In addition, with a high proportion of the mineral modifier (ratio 1/2.5), the maximum number of CSH and CASH phases is formed. This means that a lack of $\mathrm{CaO}$ is formed in the system as the main component for the synthesis of new growths. In this regard, with an increase in the concentration of the modifier in the model system, a decrease in catoite is observed.

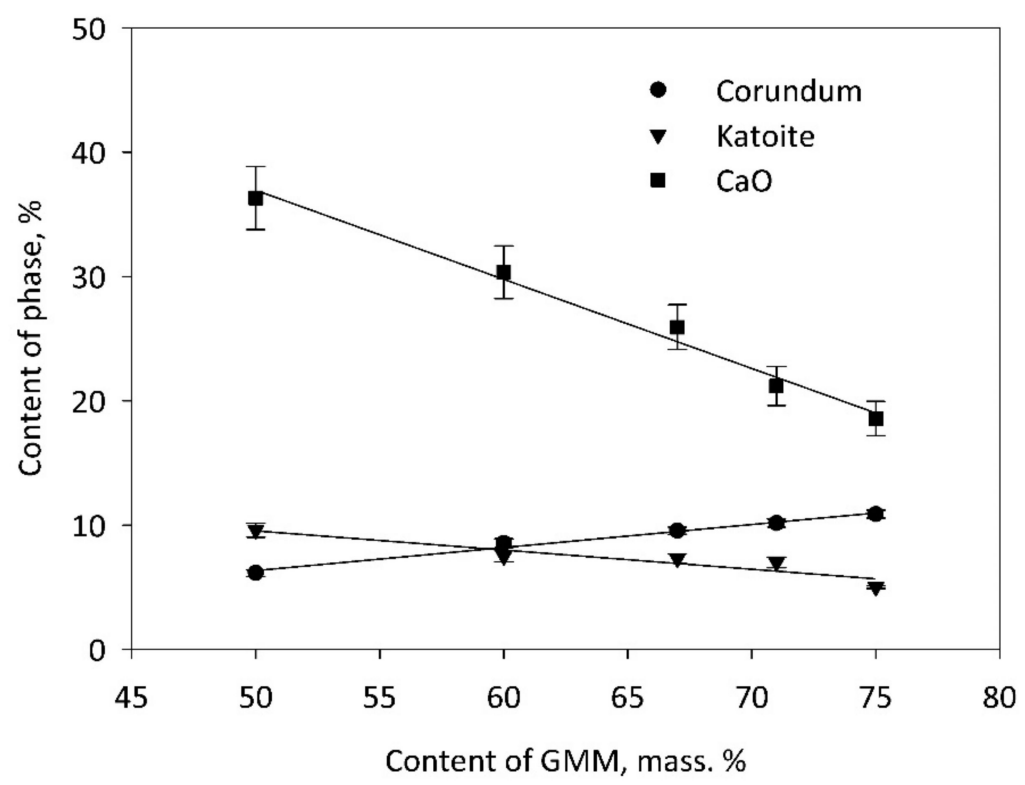

Figure 11. Correlation between contents of corundum and katoite in the binding system.

The following proves the theory of the formation of katoite from impurity corundum. Due to the octahedral coordination of $\mathrm{Al}$ for corundum and katoite (Al(VI)) compared to CASH gel and wairakite (Al(IV)) and due to the similar trend of corundum and katoite, it might be assumed that katoite forms from corundum impurities. This is confirmed by separate positions of field for $\mathrm{CaO}-\mathrm{Al}_{2} \mathrm{O}_{3}-\mathrm{SiO}_{2}-\mathrm{H}_{2} \mathrm{O}$ gel and newly-formed phases on its

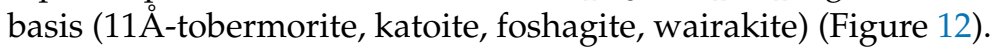




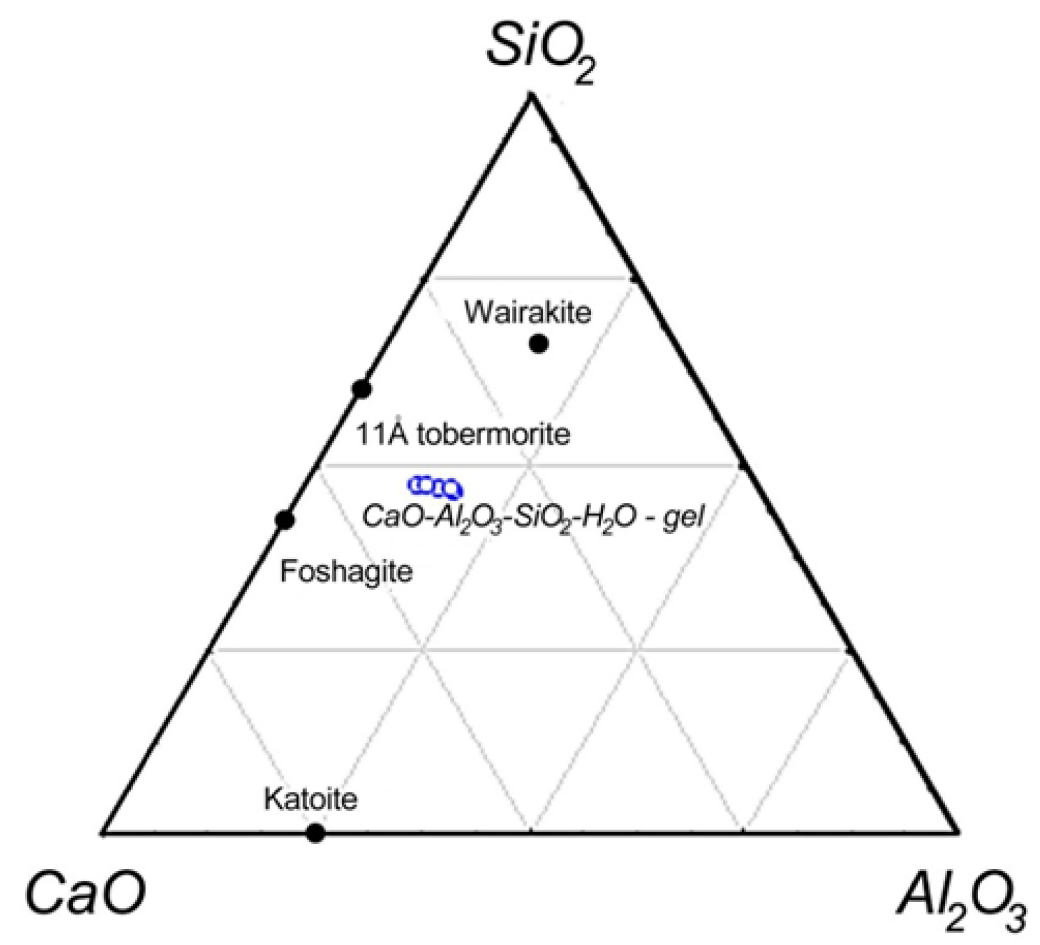

Figure 12. System of $\mathrm{CaO}-\mathrm{Al}_{2} \mathrm{O}_{3}-\mathrm{SiO}_{2}-\mathrm{H}_{2} \mathrm{O}$ gel and newly-formed phases synthesized in "quicklimeGMM" system under autoclave conditions.

The empty circles in Figure 12 show the CASH gel composition. Since the CASH gel is a four-component formation, its composition can be represented as a point in the quaternary system $\mathrm{CaO}-\mathrm{Al}_{2} \mathrm{O}_{3}-\mathrm{SiO}_{2}-\mathrm{H}_{2} \mathrm{O}$ tops. The ternary phase diagram of the $\mathrm{CaO}-$ $\mathrm{Al}_{2} \mathrm{O}_{3}-\mathrm{SiO}_{2}$ compositions shows the CASH gel compositions without water. It should be mentioned that these are hypothetical CASH gel compositions calculated based on a decrease in the concentration of quartz, albite and free lime in the studied systems.

In the study of Meller et al. [45], where corundum as alumina component in the $\mathrm{CaO}-$ $\mathrm{Al}_{2} \mathrm{O}_{3}-\mathrm{SiO}_{2}-\mathrm{H}_{2} \mathrm{O}$ was used, the katoite formation as a product of hydrothermal synthesis was observed. Bicchulite (zeolite group) was also obtained (in contrast with more hydrated wairakite, fixed in our study). Lower hydration degree of bicchulite vs. wairakite can be associated with higher treatment temperature [45].

Wairakite formation is not only a product of hydration leading to CSH-phases, it is also formed via a geopolymerisation process. Consequently, the lime-GMM binding system could be considered as system that is characterized by the superposition of two hardening mechanisms.

According to the above, the phenomenological model of phase formation in the autoclave binding system "quicklime-GMM" was proposed (Figure 13).

The left column indicates the factors affecting the mineral composition, the dominant chemical components of the binders and mineral growths. The proposed model shows the correlation of the mineral composition of the modifier as a raw material with the final phases formed in the process of hydrothermal treatment.

\subsection{Silicate Brick with GMM as Replacing Part of the Aggregates}

Analysis of the properties of brick specimens correlates with the data on phase formation: an increase in the proportion of granite modifier leads to an increase in the main characteristics of a brick (Figure 14). 


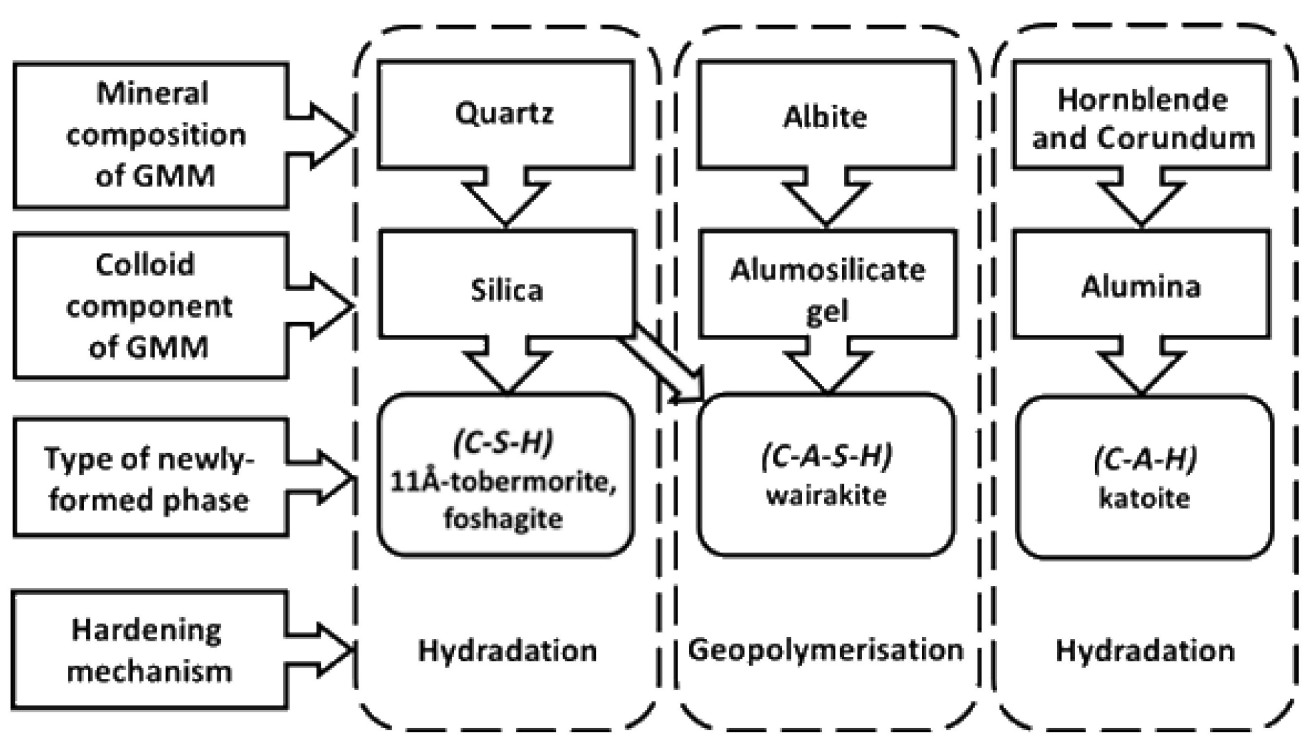

Figure 13. Phenomenological model of phase formation in the autoclave binding system "quicklime-GMM".

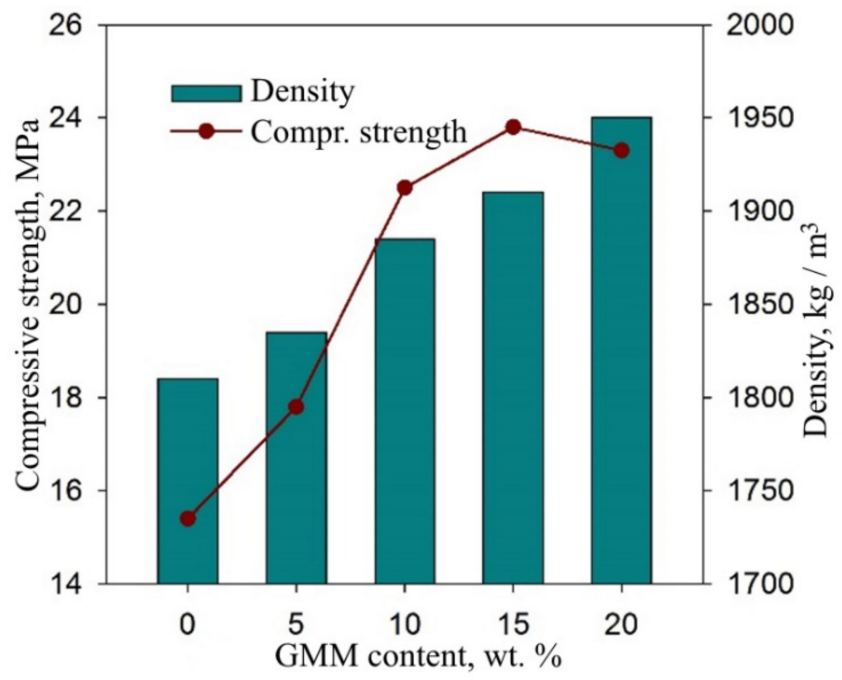

Figure 14. Physicomechanical properties of materials depending on the content of the modifier.

An increase in the content of the modifier in the system leads to a gradual increase in the density of products (Figure 13). This is due to the peculiarities of the granulometry of the polymineral modifier. The components of the original rock have different hardness and, as a result, different grindability. This leads to the formation of a polydisperse material with a wide range of particle sizes, from ultrafine to coarsely dispersed. Thus, coarsely dispersed particles of the mineral modifier act as a filler and fill the space between the larger particles of the molding mixture, which contributes to the compaction of the products.

An increase in the GMM content in the system leads to growth in the compressive strength. Thus, even at a concentration of the modifier in an amount of $5 \%$, the excess of strength is $15 \%$. Maximum strength is observed at $15 \%$ content of the mineral additive. This contributes to an increase in strength by more than $50 \%$, from 15.4 to $23 \mathrm{MPa}$. Obviously, the increase in strength is due to both a physical factor-the compaction of the system due to the different sizes of particles-and a chemical factor, the formation of a polymineral system of new growths.

According to $[28,60]$, the water absorption of masonry materials must be at least $6 \%$. This is due to the need for the formation of adhesion forces between bricks and masonry mortars during the construction of buildings. An increase in the density of finished materials can reduce the water absorption of products, which will negatively affect the adhesion 
of masonry components. It is noted that the introduction of a nanostructured modifier leads to a slight decrease in water absorption, from $12.4 \%$ to $11.7 \%$ with a nanomodifier content of $15 \%$. This is due to the optimization of the structure of the samples and the reduction in pores and voids in the product.

The properties of the masonry material, particularly its strength characteristics and the strength of adhesion to the masonry mortar, are influenced by the surface quality, features of its structure, porosity, etc. In this case, the total porosity of the composite is made up of macroporosity, formed due to defects in the preparation of the material (irrationally selected composition, incomplete compaction of the composite, entrapment of air bubbles, etc.), and microporosity associated with the hardening of the product, the quality of the filler (affecting the density the interfacial transition zone of the aggregate with the binder), etc., and, as a rule, composed of small pores and capillaries.

The use of a modifier shifts the overall porosity of the composites downward (Figure 15). An increase in the volume of nanopores is observed along with a decrease in macropores. This is due to the compaction of the structure of materials due to the use of a modifier acting as a micro-filler between larger particles of filler (quartz sand), as well as due to the synthesis of different-sized new growths of various morphologies.

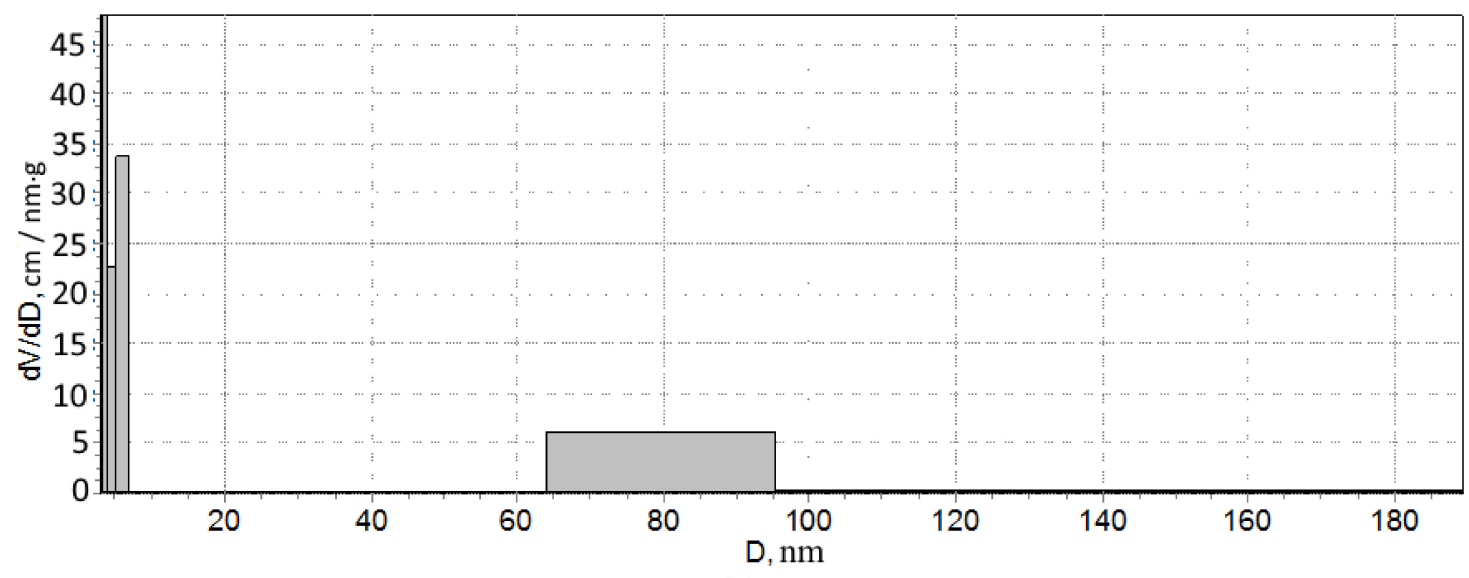

(a)

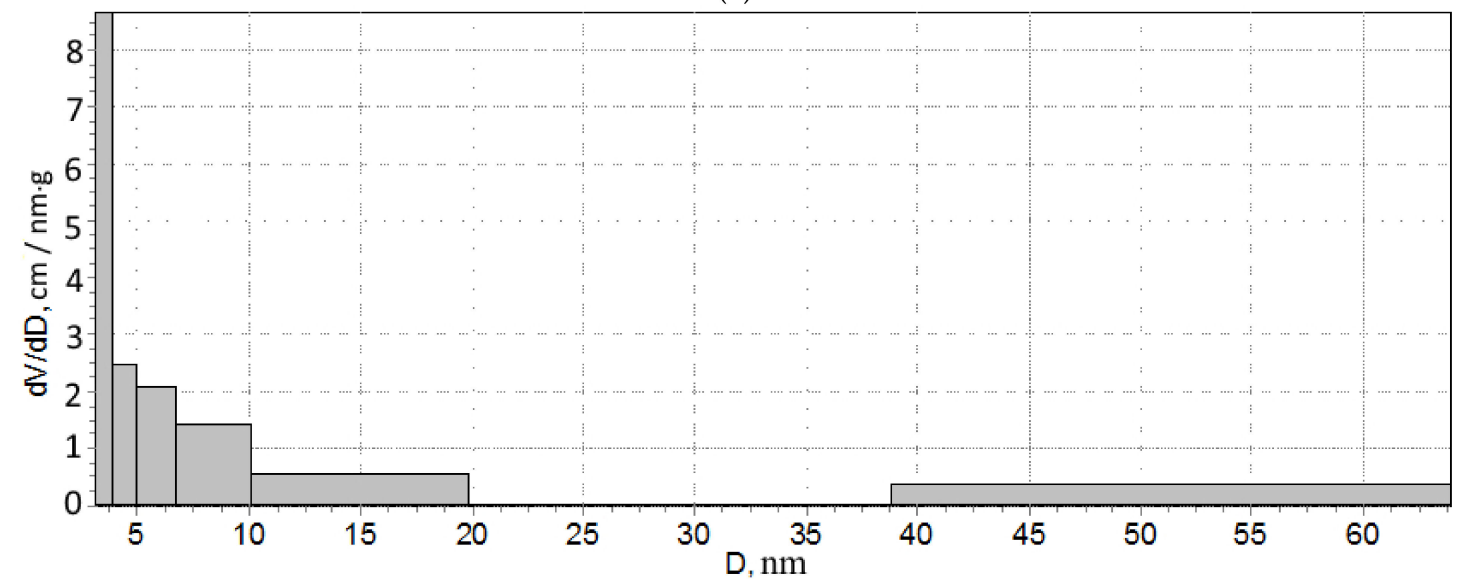

(b)

Figure 15. The porosity of the pressed composites depending on the composition: (a) control; (b) experimental with $15 \%$ GMM.

Analysis of the undisturbed specimen's surface microstructure (Figure 16) made it possible to analyze the influence of the modifier on the properties of the product in terms of the quality of the front surface or the surface in contact with the masonry mortar. Thus, samples of the control composition are characterized by a surface with a high content of pores and voids (Figure 16a,c,e). A clearly distinguishable contact zone is observed 
between the aggregate and binder grains. Larger aggregate grains are surrounded by small particles (Figure 16c). Along with monolithic zones, there are loose areas in which the bond between the components is almost completely absent.

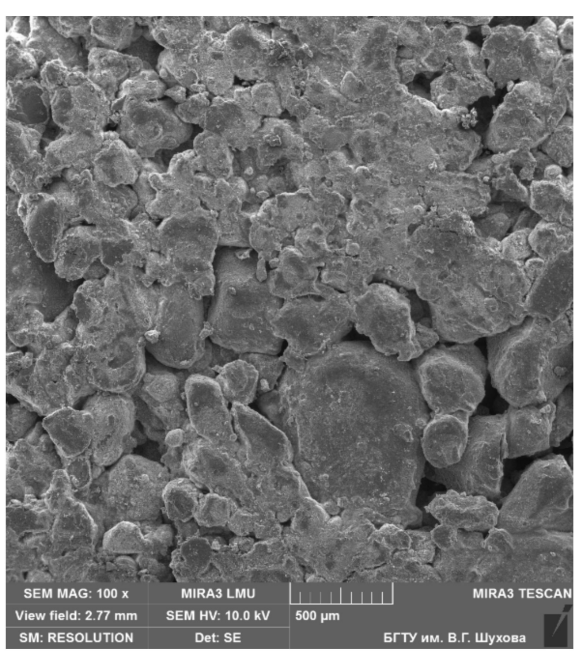

(a)

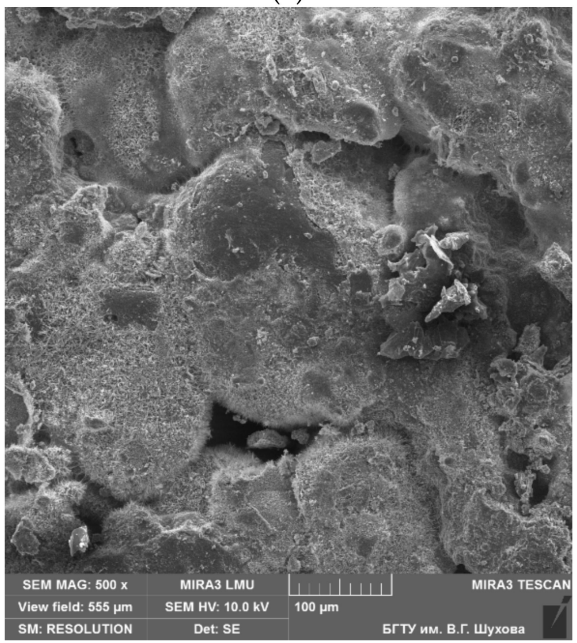

(c)

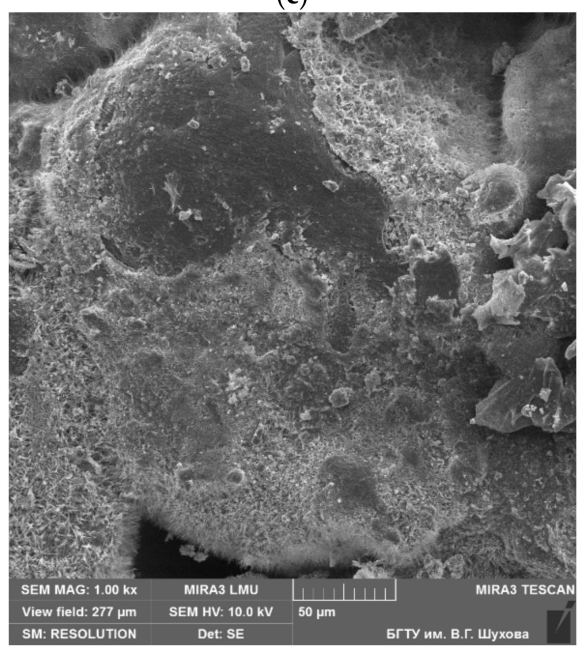

(e)

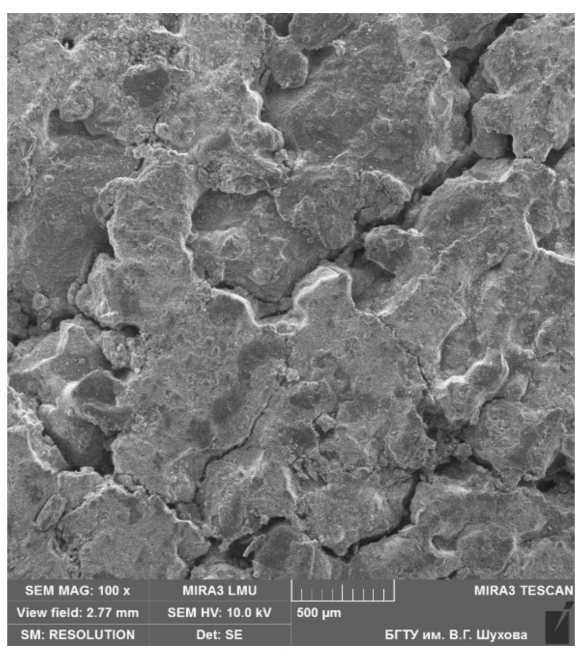

(b)

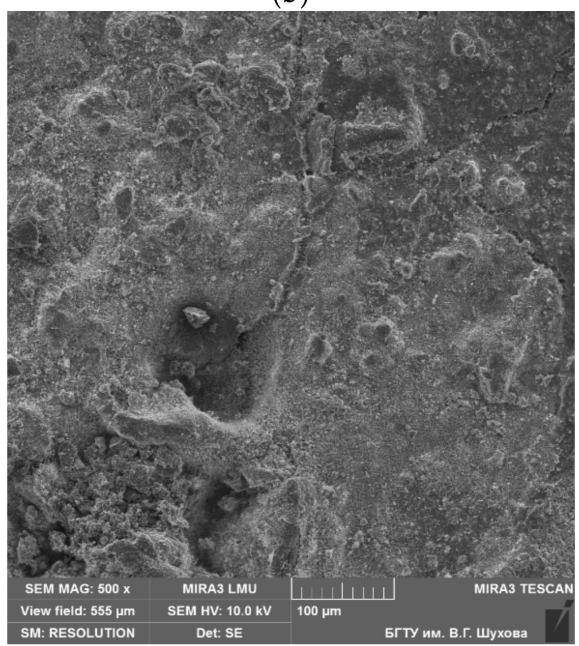

(d)

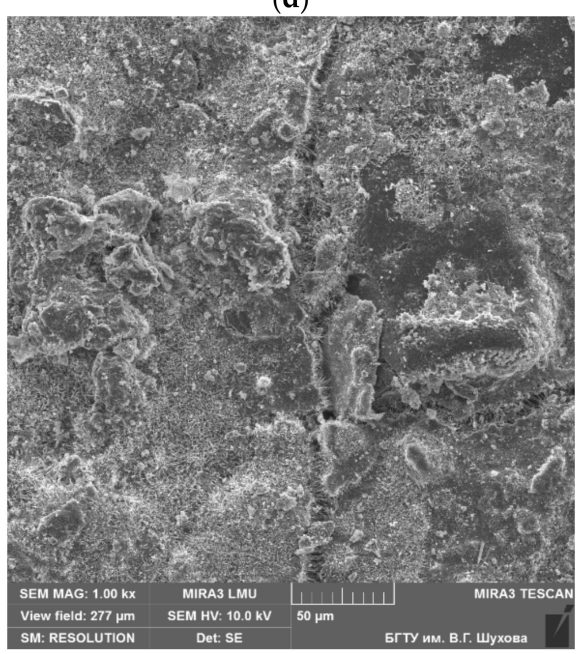

(f)

Figure 16. Surface microstructure of specimens depending on composition: $(\mathbf{a}, \mathbf{c}, \mathbf{e})$ control; $(\mathbf{b}, \mathbf{d}, \mathbf{f})$ experimental with $15 \%$ GMM. 
Experimental composites are distinguished by a uniform structure, in which the number of voids is much lower (Figure 16a,b). The filler is practically not "separable" from the volume of the entire material (Figure 16c,d). The surface of the filler in the experimental specimens (Figure 16d,f), in contrast to the control ones (Figure 16c,e), is not observed. This is due to the large amount of binder that monolithizes the aggregate. Given the same amount of lime-silica binder in the experimental and control compositions, this can be explained by the fact that the modifier, replacing the filler, being a highly dispersed component and a more active component of the binder, intensifies the formation of a larger number of new growths.

To analyze the effect of the modifier on the structure formation processes of the composite matrix and the interfacial transition zone of the aggregate with the hardened binder, the chips of the specimens of the control and experimental compositions were studied. Mechanical cracks, which are inevitable and formed during the preparation of specimens (chipping off a piece of the required size for shooting on a microscope), are characteristic of both compositions.

Specimens of the control composition are characterized by significant structural defects: cracks and loose structure of the composite are visible (Figure 16a). Druses of newly formed hydration products are observed in places of a loose structure (voids) (Figure 16c). Due to the fact that the voids are large enough, the binder is not enough for their complete overgrowth. The habit of crystals in all areas is the same-needle-like (Figure 16d), i.e., phases of the same composition prevail. This suggests that, firstly, the crystallization processes in time proceed at a constant rate and, secondly, the composition of the solution from which the crystallization of new formations occurs has a constant $\mathrm{CaO} / \mathrm{SiO}_{2}$ ratio.

The surface of aggregate particles in all compositions is characterized by a "pitted" structure, which can be both a relict aggregate structure (sand is a sedimentary rock formed as a result of physicochemical processes of sedimentogenesis), and the result of dissolution processes in the process of interaction with lime during autoclaving (Figure 17). It is possible that the alkaline environment during hydrothermal treatment enhances the results of natural corrosion.

The weakest structural element of these composites is the interfacial transition zone. This is confirmed by the fact that the fracture formed as a result of the preparation of specimens for research on a scanning microscope (the formation of a fresh cleavage), in almost all cases, passes precisely along the interfacial transition zone and through the pore space. Mechanical damage to the structure also explains the cracks at the contact of the aggregate quartz grains with the cement matrix, observed in the SEM images at various magnifications.

The material clearly shows aggregate grains covered with a newly formed substance (Figure 17b-d). Crystalline formations that form the interfacial transition zone of the aggregate with the cement matrix are mainly represented by needle-like tangled aggregates (Figure 17e). Their distribution over the surface of the aggregate and over the volume of the material is uneven. However, the adhesion of coarse crystalline phases to the surface of sand particles is weak. Fine-crystalline formations, most characteristic of specimens with GMM, cover the aggregate more evenly, creating a crust on the surface of the corroded aggregate. All this ultimately affects the strength properties of the composite as a whole.

The experimental specimens are characterized by a uniform structure. New growths of fibrous morphology almost completely cover the sand grains and also fill the intergranular voids in the bulk of the material (Figure 17b). In this case, the crystalline phases are characterized by smaller sizes in comparison with the new formations of the control composition (Figure $17 \mathrm{~d}, \mathrm{f}$ ) and play the role of microfiller in the specified system, which is proven by a change in the porosity of the composites. The filler grains are also characterized by a loose surface structure; however, in contrast to the specimens of the control composition, in this case this leads to an increase in the adhesion between the filler particles and crystalline phases. In view of the fact that most of the hydrosilicates and hydroaluminosilicates formed in the systems " $\mathrm{CaO}-\mathrm{SiO}_{2}-\mathrm{H}_{2} \mathrm{O}$ " and " $\mathrm{CaO}-\mathrm{SiO}_{2}-\mathrm{Al}_{2} \mathrm{O}_{3}-\mathrm{H}_{2} \mathrm{O}$ " have low-symmetry struc- 
tures (except for highly symmetric hydro-garnets), identification of crystalline phases by the habit of crystals using micrographs in both compositions is difficult, which is associated with their small size and similarity of morphology [61-70].

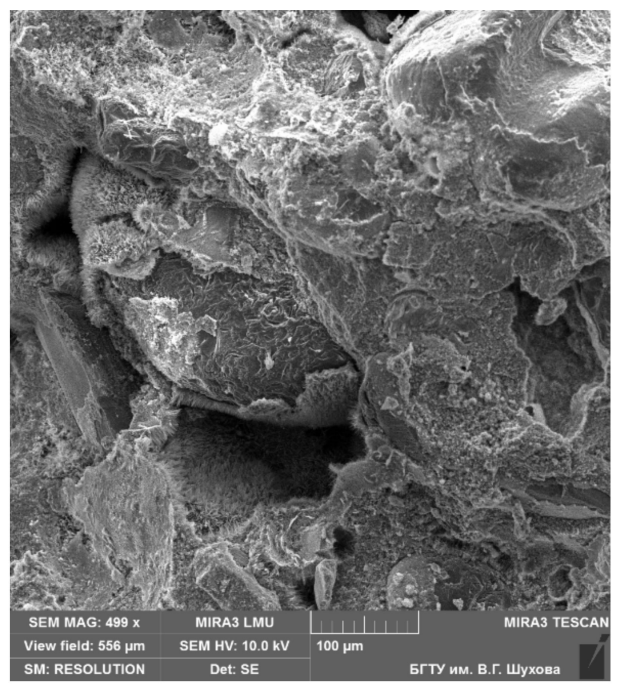

(a)

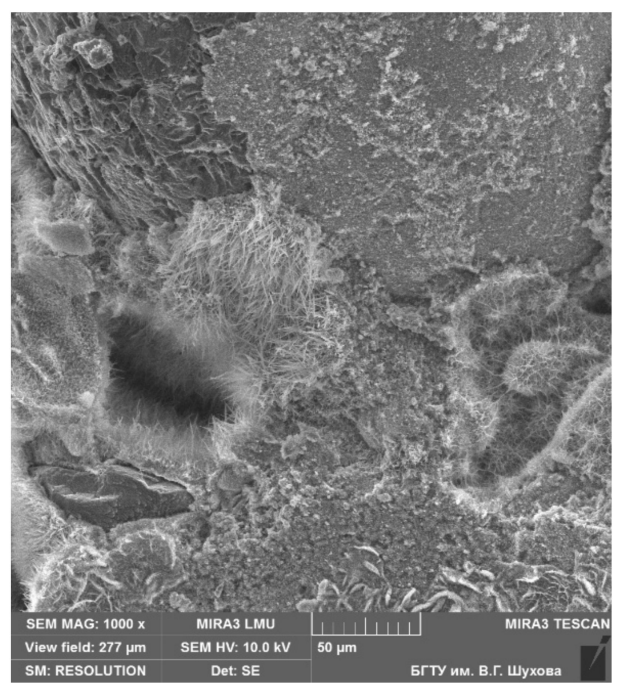

(c)

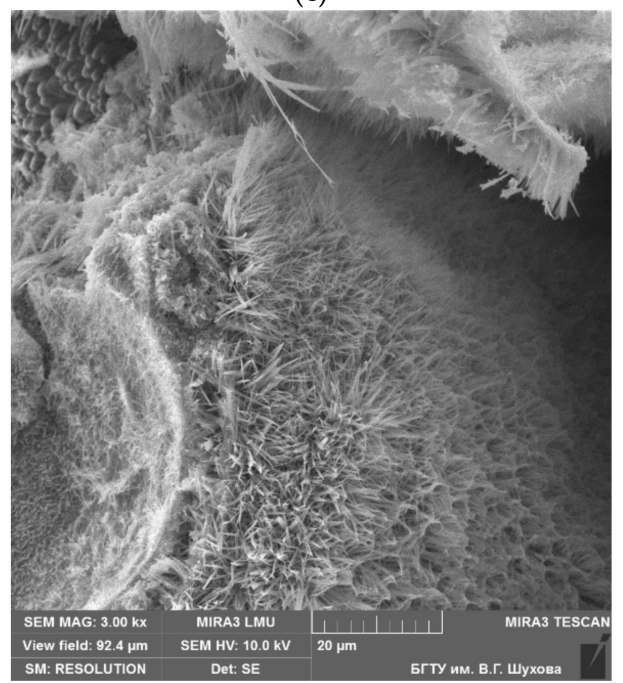

(e)

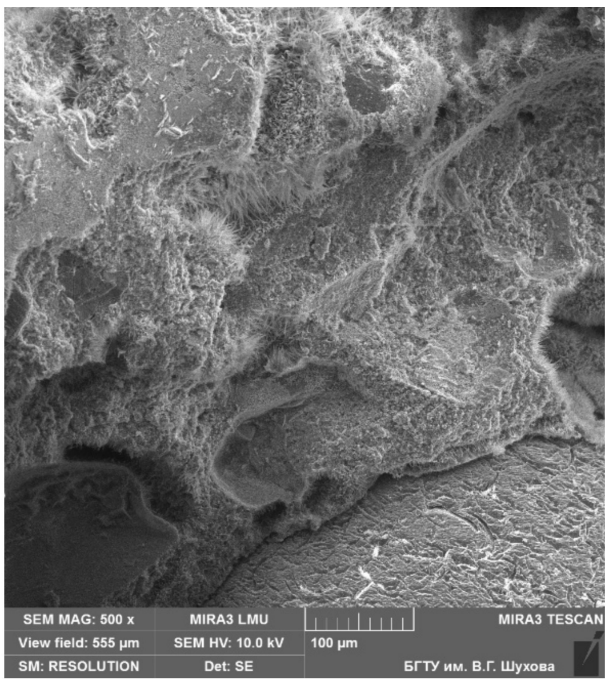

(b)

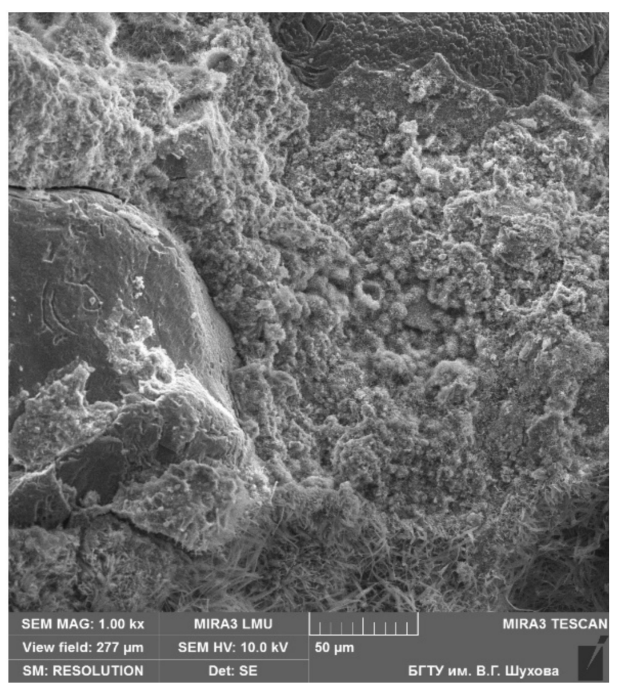

(d)

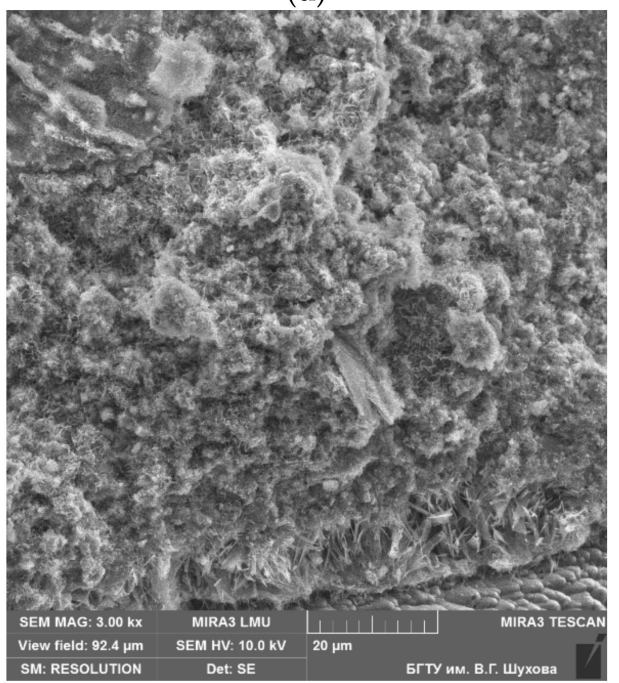

(f)

Figure 17. Microstructure of specimens depending on composition: (a,c,e) control; (b,d,f) experimental with $15 \%$ GMM. 


\section{Conclusions}

The possibility of using waste from crushing granite has been proven as a highly active additive in the production of compressed materials of autoclave hardening. As a result of the study of the influence of the granite mineral modifier on the structure formation and properties of autoclave materials, the following significant results were obtained:

(1) A phase formation in a $\mathrm{CaO}-\mathrm{SiO}_{2}-\mathrm{Al}_{2} \mathrm{O}_{3}-\mathrm{H}_{2} \mathrm{O}$ binding system during autoclaving as a result of different mixes of granite powder (as a source of $\mathrm{SiO}_{2} ; \mathrm{Al}_{2} \mathrm{O}_{3}$ ) and lime (as a source of $\mathrm{CaO}$ ) was studied. The activated silica contained in the modifier contributes to the formation of low-base calcium-silicate hydrates of the tobermorite group, the main components of the mechanical strength properties of autoclaved materials. The presence of the aluminosilicate component in the modifier leads to the formation of the zeolite phase, wairakite, which is responsible for the durability of the products in the process of their lifetime. The formation of an impurity modifying suspension in the form of corundum causes the formation of katoite hydrogarnet, whose role in the formation of physical and mechanical properties in this system cannot be determined due to the inconsistency of existing opinions about the mechanism of their influence on the final properties of products.

(2) The possibility of using a granite modifier as a component of extruded materials of autoclave hardening has been proven. The compressive strength of the samples increases with the introduction of the granite component. The introduction of $15 \%$ granite modifier instead of a part of the filler provides an increase in the strength of products by more than $50 \%$, with a slight increase in the density of the material. This makes it possible to obtain pressed products (silicate bricks) with a density of $1835-1950 \mathrm{~kg} / \mathrm{m}^{3}$, ultimate compressive strength of $17.8-23.3 \mathrm{MPa}$ and water absorption of $11.4-12.2 \%$.

(3) The features of the macro- and microstructure of autoclave bricks are shown. The introduction of a modifier into pressed composites of autoclave hardening leads to an increase in the packing density of the material and a decrease in its microporosity and surface defectiveness. Nevertheless, the shift of porosity into the nanoscale, as well as the presence of small cracks on the surface of the samples (practically closed by the newly formed substance), creates the possibility of capillary suction of materials, which will contribute to better adhesion of the masonry mortar to small-piece items.

(4) The emergence of all structural modifications of calcium carbonate- such as calcite, aragonite and vaterite-in the hardened binder should be considered among the issues that go beyond the scope of this study and require separate consideration. At present, it is not possible to confidently attribute their formation to the stage of lime production or autoclave synthesis.

Author Contributions: Conceptualization, V.N.; data curation, V.S.; formal analysis, R.F.; funding acquisition, M.A.; investigation, N.V.; methodology, Y.V.; writing-original draft, V.N., V.S., R.F., M.A., N.V. and Y.V. All authors have read and agreed to the published version of the manuscript.

Funding: The research was performed with financial support from the Russian Science Foundation (project No. 19-19-00263) using the equipment of the Center for High Technologies of BSTU named after V.G. Shukhov.

Institutional Review Board Statement: Not applicable.

Informed Consent Statement: Not applicable.

Data Availability Statement: Data sharing is not applicable to this article.

Conflicts of Interest: The authors declare no conflict of interest. 


\section{References}

1. Qu, X.Z. Previous and present investigations on the components, microstructure and main properties of autoclaved aerated concrete-A review. Constr. Build. Mater. 2017, 135, 505-516. [CrossRef]

2. Hamad, A.J. Materials, production, properties and application of aerated lightweight concrete: Review. Int. J. Mater. Sci. Eng. 2014, 2, 152-157. [CrossRef]

3. Saikia, N.; de Brito, J. Use of plastic waste as aggregate in cement mortar and concrete preparation: A review. Constr. Build. Mater. 2012, 34, 385-401. [CrossRef]

4. Chen, J.; Xu, Y.; Chen, E.M.L. Recycling and reuse of construction and demolition waste in concrete-filled steel tubes: A review. Constr. Build. Mater. 2016, 126, 641-660. [CrossRef]

5. Ahmed, A.A.; Fedyuk, R.S.; Yu, L.; Liseytsev, R.A.; Timokhin, G.M. Use of Iraq concrete scrap as filler and aggregate of heavyweight and lightweight concrete. Constr. Mater. Prod. 2020, 3, 28-39. [CrossRef]

6. Fediuk, R.S.; Ibragimov, R.A.; Lesovik, V.S.; Stoyushko, N.Y.; Gladkova, N.A. Processing equipment for grinding of building powders. In IOP Conference Series: Materials Science and Engineering; IOP Publishing: Bristol, UK, 2018; Volume 327, p. 042029.

7. Drozdyuk, T.A.; Ayzenshtadt, A.M.; Frolova, M.A.; Rama, S.V. Mineral wool composite with the use of saponite-containing mining industry waste. Constr. Mater. Prod. 2020, 3, 21-27. [CrossRef]

8. Fang, Y.; Gu, Q.; Kang, Q.; Wen, P.D. Utilization of copper tailing for autoclaved sand-lime brick. Constr. Build. Mater. 2011, 25, 867-872. [CrossRef]

9. Fediuk, R.S.; Lesovik, V.S.; Liseitsev, Y.L.; Timokhin, R.A.; Bituyev, A.V.; Zaiakhanov, M.Y.; Mochalov, A.V. Composite binders for concretes with improved shock resistance. Mag. Civ. Eng. 2019, 85. [CrossRef]

10. Mestnikov, A.; Semenov, S.; Strokova, V.; Nelubova, V. Autoclave foam concrete: Structure and properties. AIP Conf. Proc. 2016, 1698, 070010. [CrossRef]

11. Fediuk, R.; Pak, A.; Kuzmin, D. Fine-Grained Concrete of Composite Binder. In IOP Conference Series: Materials Science and Engineering; IOP Publishing: Bristol, UK, 2017.

12. Nelyubova, V.V.; Strokova, V.V.; Sumin, A.V.; Jernovskiy, I.V. The structure formation of the cellular concrete with nanostructured modifier. Key Eng. Mater. 2017, 729, 99-103. [CrossRef]

13. Qin, J.; Cui, C.; Yang, C.; Cui, X.; Hu, B.; Huang, J. Dewatering of waste lime mud and after calcining its applications in the autoclaved products. J. Clean. Prod. 2016, 113, 355-364. [CrossRef]

14. Karpikov, E.G.; Lukuttsova, N.P.; Soboleva, G.N.; Golovin, S.N.; Cherenkova, Y. Effect of microfillers based on natural wollastonite on the properties of fine-grained concrete. Constr. Mater. Prod. 2019, 2, 20-28. [CrossRef]

15. Liu, Y.; Leong, B.S.; Hu, Z.T.; Yang, E.H. Autoclaved aerated concrete incorporating waste aluminum dust as foaming agent. Constr. Build. Mater. 2017, 148, 140-147. [CrossRef]

16. Wan, H.; Hu, Y.; Liu, G.; Qu, Y. Study on the structure and properties of autoclaved aerated concrete produced with the stone-sawing mud. Constr. Build. Mater. 2018, 184, 20-26. [CrossRef]

17. Elistratkin, M.Y.; Minakov, S.V.; Shatalova, S.V. Composite binding mineral additive influence on the plasticizer efficiency. Constr. Mater. Prod. 2019, 2, 10-16. [CrossRef]

18. Wu, R.; Dai, S.; Jian, S.; Huang, J.; Tan, H.; Li, B. Utilization of solid waste high-volume calcium coal gangue in autoclaved aerated concrete: Physico-mechanical properties, hydration products and economic costs. J. Clean. Prod. 2021, 278, 123416. [CrossRef]

19. Guo, X.; Zhang, T. Utilization of municipal solid waste incineration fly ash to produce autoclaved and modified wall blocks. J. Clean. Prod. 2020, 252, 119759. [CrossRef]

20. Yuan, B.; Straub, C.; Segers, S.; Yu, Q.L.; Brouwers, H.J.H. Sodium carbonate activated slag as cement replacement in autoclaved aerated concrete. Ceram. Int. 2017, 43, 6039-6047. [CrossRef]

21. Cai, L.; Li, X.; Ma, B.; Lv, Y. Effect of binding materials on carbide slag based high utilization solid-wastes autoclaved aerated concrete (HUS-AAC): Slurry, physic-mechanical property and hydration products. Constr. Build. Mater. 2018, 188, 221-236. [CrossRef]

22. Chen, Y.L.; Ko, M.S.; Chang, J.E.; Lin, C.T. Recycling of desulfurization slag for the production of autoclaved aerated concrete. Constr. Build. Mater. 2018, 158, 132-140. [CrossRef]

23. Li, X.; Liu, Z.; Lv, Y.; Cai, L.; Jiang, D.; Jiang, W.; Jian, S. Utilization of municipal solid waste incineration bottom ash in autoclaved aerated concrete. Constr. Build. Mater. 2018, 178, 175-182. [CrossRef]

24. Fediuk, R.S.; Yevdokimova, Y.G.; Smoliakov, A.K.; Stoyushko, N.Y.; Lesovik, V.S. Use of geonics scientific positions for designing of building composites for protective (fortification) structures. In IOP Conference Series: Materials Science and Engineering; IOP Publishing: Bristol, UK, 2017; Volume 221.

25. Nelybova, V.; Pavlenko, N.; Netsvet, D. Cellular composites with ambient and autoclaved type of hardening with application of nanostructured binder. In IOP Conference Series: Materials Science and Engineering; IOP Publishing: Bristol, UK, 2015; Volume 96, p. 012010. [CrossRef]

26. Huang, X.Y.; Ni, W.; Cui, W.H.; Wang, Z.J.; Zhu, L.P. Preparation of autoclaved aerated concrete using copper tailings and blast furnace slag. Constr. Build. Mater. 2012, 27, 1-5. [CrossRef]

27. Cai, L.; Ma, B.; Li, X.; Lv, Y.; Liu, Z.; Jian, S. Mechanical and hydration characteristics of autoclaved aerated concrete (AAC) containing iron-tailings: Effect of content and fineness. Constr. Build. Mater. 2016, 128, 361-372. [CrossRef] 
28. Fediuk, R.; Yushin, A. Composite binders for concrete with reduced permeability. In IOP Conference Series: Materials Science and Engineering; IOP Publishing: Bristol, UK, 2016; Volume 116.

29. Hamza, R.A.; El-Haggar, S.; Khedr, S. Marble and granite waste: Characterization and utilization in concrete bricks. Int. J. Biosci. Biochem. Bioinf. 2011, 1, 286. [CrossRef]

30. Arivumangai, T.F.A. Strength and durability properties of granite powder concrete. J. Civ. Eng. Res. 2014, $2163-2316$.

31. Gupta, L.K.; Vyas, A.K. Impact on mechanical properties of cement sand mortar containing waste granite powder. Constr. Build. Mater. 2018, 191, 155-164. [CrossRef]

32. Sadek, D.M.; El-Attar, M.M.; Ali, H.A. Reusing of marble and granite powders in self-compacting concrete for sustainable development. J. Clean. Prod. 2016, 121, 19-32. [CrossRef]

33. Singh, S.; Nagar, R.; Agrawal, V.; Rana, A.; Tiwari, A. Sustainable utilization of granite cutting waste in high strength concrete. J. Clean. Prod. 2016, 116, 223-235. [CrossRef]

34. Ghannam, S.; Najm, H.; Vasconez, R. Experimental study of concrete made with granite and iron powders as partial replacement of sand. Sustain. Mater. Technol. 2016, 9, 1-9. [CrossRef]

35. Zafar, M.S.; Javed, U.; Khushnood, R.A.; Nawaz, A.; Zafar, T. Sustainable incorporation of waste granite dust as partial replacement of sand in autoclave aerated concrete. Constr. Build. Mater. 2020, 250, 118878. [CrossRef]

36. Cai, L.; Li, X.; Liu, W.; Ma, B.; Lv, Y. The slurry and physical-mechanical performance of autoclaved aerated concrete with high content solid wastes: Effect of grinding process. Constr. Build. Mater. 2019, 218, 28-39. [CrossRef]

37. Klyuev, S.; Klyuev, A.; Vatin, N. Fine-grained concrete with combined reinforcement by different types of fibers. MATEC Web Conf. 2018, 245, 5. [CrossRef]

38. Chernysheva, N.V.; Lesovik, V.S.; Drebezgova, M.Y.; Shatalova, S.V.; Alaskhanov, A.H. Composite Gypsum Binders with Silica-containing Additives. In IOP Conference Series: Materials Science and Engineering; IOP Publishing: Bristol, UK, 2018.

39. Wu, R.; Dai, S.; Jian, S.; Huang, J.; Lv, Y.; Li, B.; Azizbek, N. Utilization of the circulating fluidized bed combustion ash in autoclaved aerated concrete: Effect of superplasticizer. Constr. Build. Mater. 2020, 237, 117644. [CrossRef]

40. Tang, T.; Cai, L.; You, K.; Liu, M.; Han, W. Effect of microwave pre-curing technology on carbide slag-fly ash autoclaved aerated concrete (CS-FA AAC): Porosity rough body formation, pore characteristics and hydration products. Constr. Build. Mater. 2020, 263, 120112. [CrossRef]

41. Nakhaev, M.R.; Salamanova, M.S.; Ismailova, Z.K. Regularities of the processes of formation of the structure and strength of a clinker-free binder of alkaline activation. Constr. Mater. Prod. 2020, 3, 21-29. [CrossRef]

42. Garbev, K. Struktur, Eigenschaften und Quantitative Rietveldanalyse von Hydrothermal Kristallisierten Calciumsilikathydraten (C-S-H-Phasen). Ph.D. Thesis, Universität Heidelberg, Heidelberg, Germany, 2004.

43. Richardson, I.G. The calcium silicate hydrates. Cem. Concr. Res. 2008, 38, 137-158. [CrossRef]

44. Taylor, H.F.W. Cement Chemistry, 2nd ed.; Thomas Telford Publishing: London, UK, 1997.

45. Meller, N.; Kyritsis, K.; Hall, C. The mineralogy of the $\mathrm{CaO}-\mathrm{Al}_{2} \mathrm{O}_{3}-\mathrm{SiO}_{2}-\mathrm{H}_{2} \mathrm{O}(\mathrm{CASH})$ hydroceramic system from 200 to $350{ }^{\circ} \mathrm{C}$. Cem. Concr. Res. 2009, 39, 45-53. [CrossRef]

46. Mitsuda, T.; Taylor, H.F.W. Normal and anomalous tobermorites. Mineral. Mag. 1978, 42, 229-235. [CrossRef]

47. Biagioni, C.; Merlino, S.; Bonaccorsi, E. The tobermorite supergroup: A new nomenclature. Mineral. Mag. 2015, 79, 485-495. [CrossRef]

48. Kühnel, R.A.; Van der Gaast, S.J. Formation of clay minerals by mechanochemical reactions during grinding of basalt under water. Appl. Clay Sci. 1989, 4, 295-305. [CrossRef]

49. He, C.; Osbaeck, B.; Makovicky, E. Pozzolanic reactions of six principal clay minerals: Activation, reactivity assessments and technological effects. Cem. Concr. Res. 1995, 25, 1691-1702. [CrossRef]

50. Tromans, D.; Meech, J.A. Enhanced dissolution of minerals: Stored energy, amorphism, and mechanical activation. Miner. Eng. 2001, 14, 1359-1377. [CrossRef]

51. Chaikina, M.V.; Kryukova, G.N. Structural transformations in quartz and apatite on mechanical activation. J. Struct. Chem. 2004, 45, 121. [CrossRef]

52. Nelyubova, V.V. The composition and properties of autoclaved gas concrete with amorphized raw modifiers. Mater. Sci. Forum 2020, 974, 142-148. [CrossRef]

53. Nelyubova, V.V.; Sivalneva, M.N.; Bondarenko, D.O.; Baskakov, P.S. Study of activity of polydisperse mineral modifiers via unstandardized techniques. J. Phys. Conf. Ser. 2018, 1118, 012029. [CrossRef]

54. Nelyubova, V.V.; Strokova, V.V.; Popov, A.L.; Bezdrodnykh, A.A. Investigation of the structural topological characteristics of mechanically activated Sialic raw materials. Mater. Sci. Forum 2018, 945, 182-187. [CrossRef]

55. Kapusta, M.N.; Kobzev, V.; Nelubova, V.V. Kinetics of mechanical activation during the manufacturing process of nanostructured binders. Appl. Mech. Mater. 2014, 670-671, 412-416. [CrossRef]

56. Hickson, C.J.; Juras, S.J. Sample contamination by grinding. Can. Mineral. 1986, 24, 585-589.

57. Takamasa, A.; Nakai, S.I. Contamination introduced during rock sample powdering: Effects from different mill materials on trace element contamination. Geochem. J. 2009, 43, 389-394. [CrossRef]

58. Aranda, M.A.; De la Torre, A.G.; León-Reina, L. Rietveld quantitative phase analysis of OPC clinkers, cements and hydration products. Rev. Mineral. Geochem. 2012, 74, 169-209. [CrossRef] 
59. Guirado, F.; Gal1, S.; Chinchón, S. Quantitative Rietveld analysis of aluminous cement clinker phases. Cem. Concr. Res. 2014, 30, 1023-1029. [CrossRef]

60. Haridharan, M.K.; Matheswaran, S.; Murali, G.; Abid, S.R.; Fediuk, R.; Mugahed Amran, Y.H.; Abdelgader, H.S. Impact response of two-layered grouted aggregate fibrous concrete composite under falling mass impact. Constr. Build. Mater. 2020. [CrossRef]

61. Calligaris, G.A.; Franco, M.K.; Aldrige, L.P.; Rodrigues, M.S.; Beraldo, A.L.; Yokaichiya, F.; Turrillas, X.; Cardoso, L.P. Assessing the pozzolanic activity of cements with added sugar cane straw ash by synchrotron X-ray diffraction and Rietveld analysis. Constr. Build. Mater. 2015, 98, 44-50. [CrossRef]

62. Choudhary, H.K.; Anupama, A.V.; Kumar, R.; Panzi, M.E.; Matteppanavar, S.; Sherikar, B.N.; Sahoo, B.; Matteppanavar, B.N.; Sherikar, B.S. Observation of phase transformations in cement during hydration. Constr. Build. Mater. 2015, 101, 122-129. [CrossRef]

63. Solovyov, L.A. Full-profile refinement by derivative difference minimization. J. Appl. Crystallogr. 2014, 37, 743-749. [CrossRef]

64. Loganina, V.; Sergeeva, K.; Fediuk, R.; Uvarov, V.; Vatin, N.; Vasilev, Y.; Amran, M.; Szelag, M. Increase the Performances of Lime Finishing Mixes Due to Modification with Calcium Silicate Hydrates. Crystals 2021, 11, 399. [CrossRef]

65. Lesovik, V.; Chernysheva, N.; Fediuk, R.; Amran, M.; Murali, M.; de Azevedo, A.R.G. Optimization of fresh properties and durability of the green gypsum-cement paste. Constr. Build. Mater. 2021, 287, 123035. [CrossRef]

66. Tolstoy, A.; Lesovik, V.; Fediuk, R.; Amran, M.; Gunasekaran, M.; Vatin, N.; Vasilev, Y. Production of Greener High-Strength Concrete Using Russian Quartz Sandstone Mine Waste Aggregates. Materials 2020, 13, 5575. [CrossRef] [PubMed]

67. Abid, S.R.; Murali, G.; Amran, M.; Vatin, N.; Fediuk, R.; Karelina, M. Evaluation of Mode II Fracture Toughness of Hybrid Fibrous Geopolymer Composites. Materials 2021, 14, 349. [CrossRef] [PubMed]

68. Lesovik, V.; Volodchenko, A.; Fediuk, R.; Mugahed Amran, Y.H.; Timokhin, R. Enhancing performances of clay masonry materials based on nanosize mine waste. Constr. Build. Mater. 2021, 269, 121333. [CrossRef]

69. Amran, M.; Murali, G.; Khalid, N.H.A.; Fediuk, R.; Ozbakkaloglu, T.; Lee, Y.H.; Haruna, S.; Lee, Y.Y. Slag uses in making an ecofriendly and sustainable concrete: A review. Constr. Build. Mater. 2021, 272, 121942. [CrossRef]

70. Lesovik, V.; Voronov, V.; Glagolev, E.; Fediuk, R.; Alaskhanov, A.; Mugahed Amran, Y.H.; Murali, G.; Baranov, A. Improving the behaviors of foam concrete through the use of composite binder. J. Build. Eng. 2020, 31, 101414. [CrossRef] 